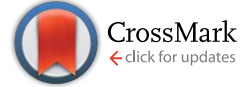

Cite this: Nat. Prod. Rep., 2015, 32, 1042

Received 20th January 2015

DOI: 10.1039/c5np00006h

www.rsc.org/npr

\section{The use of the lactone motif in chemical communication}

\author{
Stefan Schulz and Susann Hötling
}

Covering: up to 2014

A wide variety of organisms communicate via the chemical channel using small molecules. A structural feature quite often found is the lactone motif. In the present paper, the current knowledge on such lactones will be described, concentrating on the structure, chemistry, function, biosynthesis and synthesis of these compounds. Lactone semiochemicals from insects, vertebrates and bacteria, which this article will focus on, are particularly well investigated. In addition, some ideas on the advantageous use of lactones as volatile signals, which promoted their evolutionary development, will be discussed.
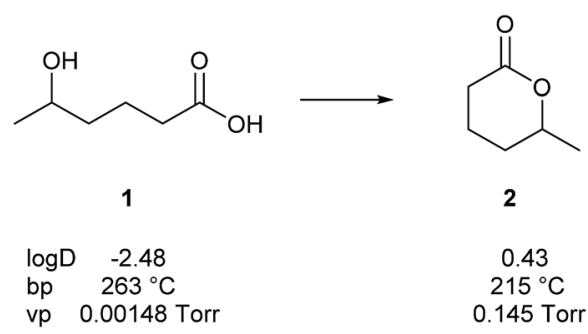

Fig. 1 Calculated values $\uparrow$ of the octanol/water partition coefficient $(\log D)$, boiling point (bp), and vapour pressure (vp) of hydroxy acid 1 and its cyclization product 2 .

But which compounds are actually active information transfer entities? Unfortunately, especially the chemical synthetic literature is sometimes misleading when biological effects are described. For example, $(S)$-4-hexanolide has been repeatedly synthesized and claimed to be a pheromone of Trogoderma beetles, important pests of stored products. Though correctly identified, no function of the compounds in chemical communication has ever been proven. ${ }^{4,5}$ The sex pheromone of various Trogoderma sp. is indeed (Z)- and/or (E)-14-methyl-8hexadecenal. This example underlines the need for critical evaluation of the literature.

In our review we will present the structures and functions of lactones used in chemical communication systems by different organisms. We will focus mostly on insects and bacteria, because many lactones are used by these organisms. But before doing so, a short discussion will show why this motif is a "privileged structure" for communication in nature.

$\dagger$ The values were calculated using ACDLabs software. 
Lactones are cyclic esters of hydroxy acids. Hydroxy acids or their activated forms are usually the natural precursors in the biosynthesis of lactones. Fig. 1 shows some calculated values of physical constants of 5-hydroxypentanoic acid (1) and its cyclization product, lactone 2 . With cyclization, the vapour pressure rises by a factor of 100 and the boiling point decreases. The lactone is, therefore, much better suited to serve as a volatile chemical signal than the hydroxy acid. Similarly, the octanol/water partition coefficient rises by a factor of 1000. Therefore, the passage through lipophilic membranes without a transporter is easier for 2 than $\mathbf{1}$, making the former better suited as a general signal transporter. Furthermore, the hydroxy acid is largely deprotonated at physiological $\mathrm{pH}$, further increasing the hydrophilicity and decreasing the vapour pressure.

Another relevant aspect seems to be the short biosynthetic transformation needed to get from 1 to 2 . The signal precursor, i.e. the hydroxy acid, can be stored, e.g. in a pheromone gland, until it is needed. A simple cyclization, probably after activation of the acid group, furnishes the lactone, ready for it to leave the gland or cell. The cyclization of $\mathbf{1}$ is also entropically favourable. Finally, inactivation of the signal, an important process following perception, can be readily achieved by simple hydrolysis via enzymes. Nevertheless, in some cases hydroxy acids serve as pheromone components themselves, without concomitant lactone formation, e.g. (E)-9-hydroxydec-2-enoic acid, a component of the queen retinue pheromone of the honey bee, Apis mellifera. ${ }^{6}$

Most of the lactones discussed here originate from fatty acid biosynthesis, but other biosynthetic pools are also used. These comprise polyketides, amino acids, and terpenes. In the following chapters, selected different signalling lactones will be described and their occurrence, function, and biosynthesis as well as their synthesis will be described, focusing on the last 20 years.

\section{Small ring lactones}

Only a few semiochemicals with a $\beta$-propiolactone ring have been described. Vittatalactone (9) and its minor nor-derivative 16 have been isolated from the striped cucumber beetle, Acalymma vittatum (Coleoptera: Chrysomelidae). ${ }^{7}$ These male specific compounds show electrophysiological activity in antennae of both sexes, and were suggested to act as an aggregation pheromone, ${ }^{7,8}$ but no behavioural studies have been reported. The absolute configuration shown has been deduced by total synthesis of the enantiomers., ${ }^{\mathbf{9}, 10}$ Breit et al. developed a highly efficient synthesis starting from mesoanhydride 3. Lipase catalysed desymmetrization led to 4 which was further transformed into the bromide 5 . The respective copper reagent introduced the next stereogenic centre by enantioselective allylic substitution, guided by the voluminous $o$-diphenyl-phosphinobenzoyl group. The allylic alcohol 6 was subjected to Sharpless epoxidation. Epoxide opening by a methylcopper reagent led to alcohol $\mathbf{8}$ which was further transformed into $\mathbf{9}$ via the hydroxy acid and lactonization by tosyl chloride (Fig. 2). ${ }^{10}$ The synthesis comprised 11 steps with an overall yield of $18 \%$. Schneider et al. used the Evans aldol product $\mathbf{1 0}$ as the precursor for a Cope rearrangement to synthesize 11. After stereoselective introduction of the C-2 methyl group (12) and iridium catalysed enantioselective hydrogenation of the enol ether group, followed by additional functional group manipulation, furnished $\mathbf{1 3}$ that was elongated by Grignard chemistry. A chiral auxiliary aldol condensation to form $\mathbf{1 5}$ set the stage for a final auxiliary cleavage and tosyl chloride mediated lactonization to give $\mathbf{9 . 1 1 , 1 2}$ Norvittatalactone 16 was obtained via the same route (Fig. 3). ${ }^{12}$ Finally, a desymmetrization and auxiliary-controlled asymmetric alkylation strategy was used to obtain both enantiomers of $9 .{ }^{13}$

Although no studies on the biosynthesis of $\beta$-lactones have been performed, it seems likely that they are formed via a fatty

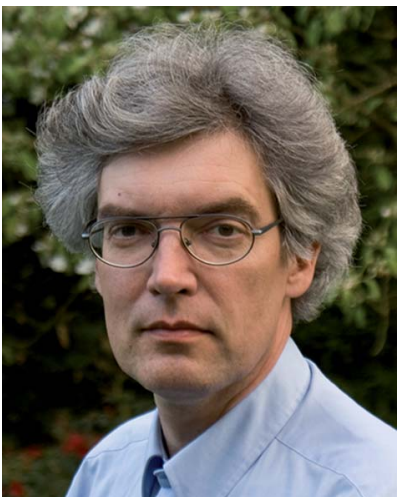

Prof. Dr. Stefan Schulz studied chemistry at the University of Hamburg, Germany. He received his PhD under the guidance of Prof. Wittko Francke. In 1988, he took up a postdoctoral position with Prof. Jerrold Meinwald at Cornell University, Ithaca, USA, elucidating the biosynthesis of pheromones derived from pyrrolizidine alkaloids. After returning to Hamburg, he

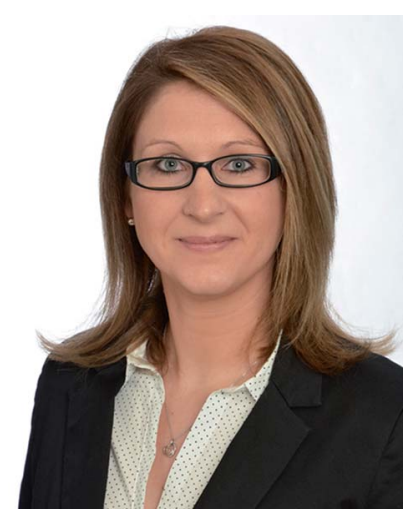

worked on his habilitation, focusing on spider pheromones. In 1997, he became Full Professor of Organic Chemistry at the Technische Universität Braunschweig. His major research areas are the identification, synthesis, biosynthesis, and function of signaling compounds released by diverse organisms, including bacteria, invertebrates and vertebrates.
Susann Hötling studied chemistry at the Technische Universität Braunschweig, Germany. Her diploma thesis focused on the identification and synthesis of macrolide pheromones of the grain beetle, Oryzaephilus surinamensis, under the guidance of Prof. Stefan Schulz. Since 2010, she has been working on her PhD in the Schulz work group. Her research interest is the identification and synthesis of lactones and terpenes as pheromones in insects and amphibia. 


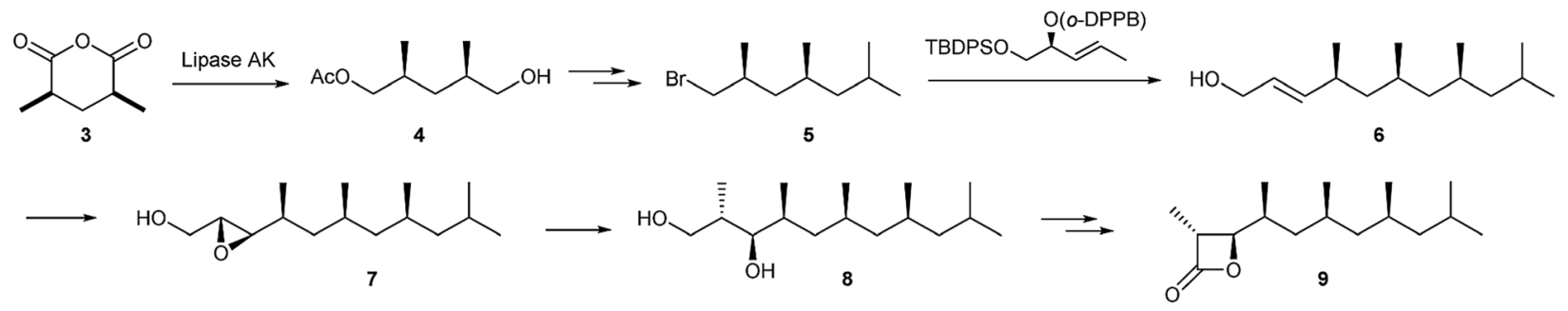

Fig. 2 Breit's synthesis of vittatalactone (9). ${ }^{10}$ o-DPPB: o-diphenylphosphinobenzoyl; TBDPS: tert-butyldiphenylsilyl.

acid biosynthesis pathway employing propionate (methylmalonate) building blocks as the source of the methyl branches. A precursor acid such as 3-hydroxypentamethyl-undecanoic acid is then cyclized to form the $\beta$-lactone. These lactones contain five stereogenic centres, the highest number of any insect semiochemical known today.

The only other known $\beta$-lactones used as semiochemicals are viridiflorine- $\beta$-lactone (25) and norviridiflorine- $\beta$-lactone (26), originally identified in the tropical butterfly Idea leuconoe (Danainae). ${ }^{14-16}$ The major $\beta$-lactone 25 is a component of the male sex pheromone of this butterfly, attracting females over short distances. ${ }^{14}$ It has also been identified in the abdominal scent glands of another danaine, Euploea mulciber, ${ }^{17}$ and in the wing androconia of Melinaea menophilus and Scada kusa males, two ithomiine clearwing butterflies phylogentically related to the danaines. ${ }^{18}$ The lactones are produced by these butterflies from the pyrrolizidine alkaloids (PAs) lycopsamine (17) and ideamine (20), which are sequestered by the adults. ${ }^{14,17}$ Adult males of danaine and ithomiine butterflies as well as several moth genera actively search for PAs for protection (pharmacophagy). Some of the PAs are converted into pheromone components such as danaidone (18) or hydroxydanaidal (19), but the majority is transferred to the female during copulation. ${ }^{19}$ The female protects her eggs with the alkaloids. Only a few species produce the $\beta$-lactones or ithomiolide (23) mentioned in the next chapter.
The PAs ingested by the butterflies are cleaved to liberate the $\beta$-lactone precursors virdifloric acid and norviridifloric acid (21, 22), which are then cyclized (Fig. 4). Biosynthetic studies on the diastereomer of 21, trachelanthic acid, showed that this acid is formed in PA producing plants from valine and pyruvate after transamination and thiamine induced addition. ${ }^{20}$

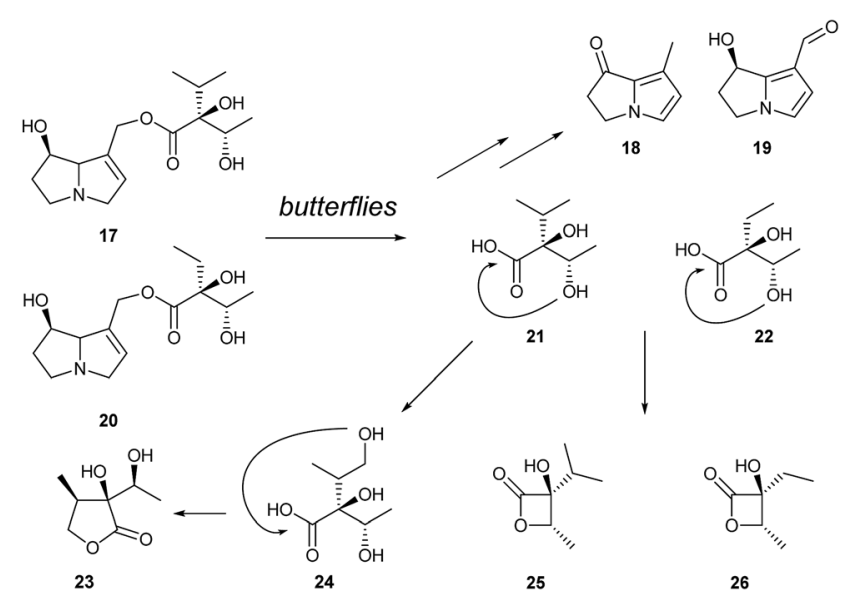

Fig. 4 Danaine and ithomiine butterflies take up pyrrolizidine alkaloids and cleave them to produce pheromones. The base part is converted to alkaloid pheromones like danaidone (18) or hydroxydanaidal (19). The acids liberated from lycopsamine (17) or ideamine (20) are cyclized into viridiflorine $\beta$-lactone (25) and norviridiflorine $\beta$-lactone (26).<smiles>CCC(C)CC(C)CC(C)CC(C)C(=O)N1C(=O)OCC1Br</smiles>

10

11

12

13

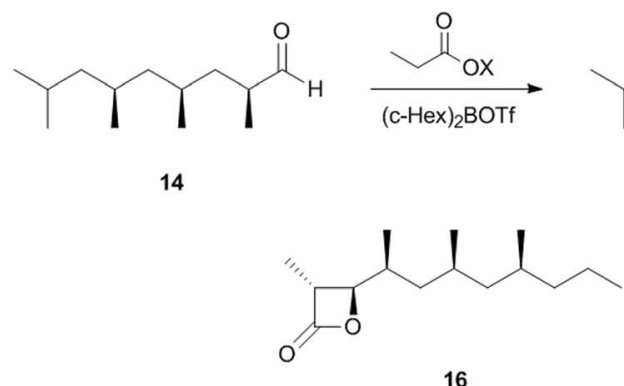

16

Fig. 3 Synthesis of vittatalactone (9) according to Schneider et al. $\mathrm{X}=(1 R, 2 S)-N$-benzyl- $N$-mesitylsulfonylnorephedrine. 


\section{Five- and six-membered ring lactones}

Five- and six-membered lactones are formed particularly easily from respective hydroxy acids. Various variants of these lactones are used in chemical communication. Male ithomiines used in addition to the compounds described so far include ithomiolide A (23) as a semiochemical. ${ }^{21}$ The biological significance of this compound is unknown, but attraction ${ }^{22}$ or repellency ${ }^{21}$ have been postulated. A survey on species from 30 ithomiine genera showed that ithomiolide A is used only by Callithomia, Ithomia, Ceratinia, Pteronymia, Episcada, Prittwitzia, Godyris, Hetereosais, Pseudoscada, and Greta. ${ }^{18}$ All genera are more highly derived, while the phylogenetically basal orders do not contain it. The biosynthesis of 23 requires oxidation of the precursor acid 21, followed by cyclization (Fig. 4). Acid $\mathbf{2 4}$ has not been reported from any PA yet. It therefore seems likely that the oxidation of the terminal methyl group has been an invention of a common ancestor of the newer ithomiine genera. It seems likely that an additional signal is needed by the butterflies because PA derived compounds such as $\mathbf{1 9}$ can also be formed by withering plants, making its use as a signal problematic. ${ }^{18}$

Many simple aliphatic $\gamma$ - and $\delta$-lactones such as 4-butanolide, 4- and 5-decanolide and unsaturated analogues like jasmine lactone, $(Z)$-dec-7-en-4-olide, have been reported as flower volatiles ${ }^{23}$ or from other sources, e.g. bacteria. ${ }^{24}$ In some cases the involvement in attraction or repellency of insects has been reported. ${ }^{25} 4$-Octanolide of unknown stereochemistry (32) is the major constituent of the alarm pheromone of the giant honey bee, Apis dorsata. ${ }^{26}$ Additional compounds such as
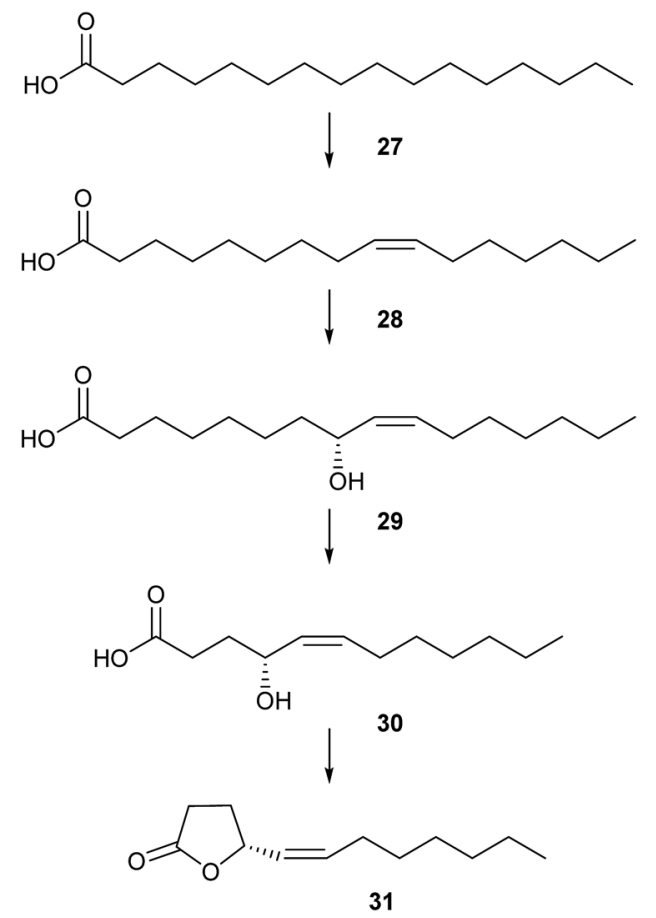

Fig. 5 Biosynthesis of buibuilactone (31) in Anomala cuprea. isopentyl acetate and (E)-2-decenyl acetate enhanced the pheromonal activity.

Unsaturated aliphatic $\gamma$-lactones are used by scarab beetles as pheromones. Buibuilactone, $(R, Z)$-dodec-5-en-4-olide (31), is a sex pheromone component of various scarab beetles of the genus Anomala. ${ }^{27-31}$ The biosynthesis of $\mathbf{3 1}$ has been investigated in detail in Anomala cuprea by feeding experiments with deuterated palmitic acid (Fig. 5). ${ }^{32}$ Hexadecanoic acid (27) is transformed into (Z)-9-hexadecenoic acid (28) by the action of a $\Delta 9$-desaturase. The stereogenic centre is introduced by allylic oxidation of a 8-hydroxylase furnishing $(R, Z)$-8-hydroxyhexadec9-enoic acid (29) with high chain length specificity. Two $\beta$ oxidation steps and subsequent cyclization complete the biosynthesis of 31. This pathway is in agreement with the biosynthesis of saturated lactones in other organisms, e.g. fungi. ${ }^{33}$ Buibuilactone has also been reported from marine bacteria of the Roseobacter clade. ${ }^{34}$

Several related lactones are female sex pheromones of scarab beetles. The bishomologue japonilure (Z)-tetradec-5-en-4-olide (36) is used by the Japanese beetle, Popillia japonica, as the $R$ enantiomer, while the $S$-enantiomer is produced by the Osaka beetle, Anomala osakana. Both beetles share the same habitat and are antagonized by the pheromone of the other species. Trap catches of Popillia japonica were dramatically reduced when the synthetic compounds used contained small amounts of the wrong enantiomer ${ }^{35}$ compellingly showing the importance of enantiomerically pure compounds in pheromone applications. The stereoisomer E-36 of Popillia japonica is slightly active, but has no synergistic activity. ${ }^{35}$ The Japanese beetle possesses two olfactory receptor neurones, each tuned separately to either the $R$ or $S$-enantiomer of 36. A pheromone degrading esterase enzyme removes the signal from the antennae. ${ }^{36}$ The importance of enantiomerically pure products is obvious, because materials with more than $99 \%$ ee are needed for full activity.

The different synthetic approaches to both $\mathbf{3 1}$ and $\mathbf{3 6}$ have been discussed. ${ }^{34,37}$ Generally, chiral pool approaches ${ }^{34,38}$ proved to be superior to the use of chiral reduction or alkylation, because the $e e$ in the latter cases did not exceed $98 \%$.

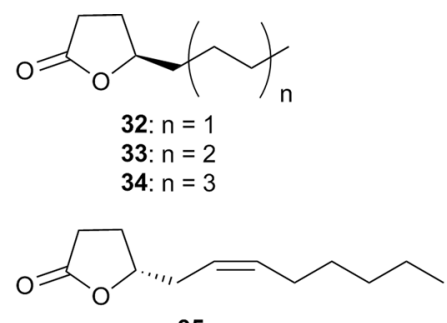

35

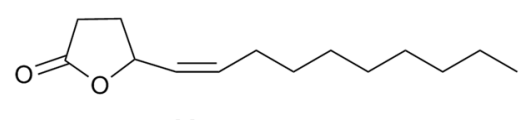

36

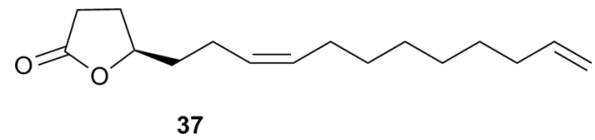




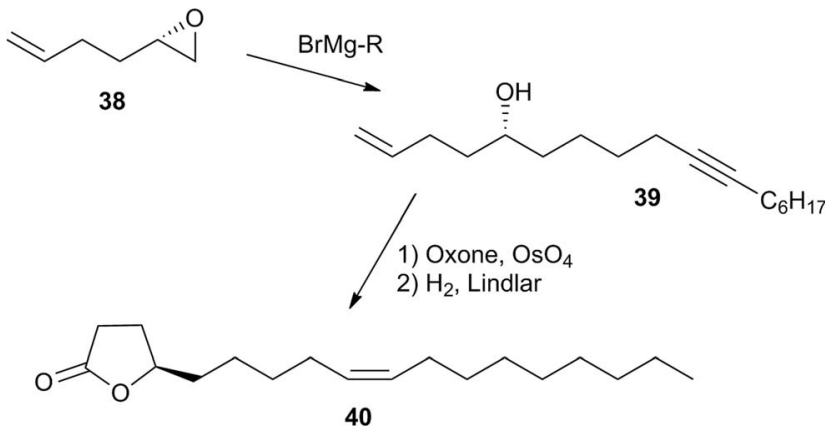

Fig. 6 Boland's synthesis of enantiomerically pure lactones. ${ }^{47}$

$(R)$-4-Decanolide (33) is the male sex pheromone of the scarab beetle Osmoderma eremita. ${ }^{39}(R, Z)-7,15$-hexadecadien-4-olide (37) is the female sex pheromone of the yellowish elongate chafer Heptophylla picea. ${ }^{\mathbf{4 0 , 4 1}}$ It has been synthesized by repeated lipase catalyzed resolution of a hydroxyester intermediate in $95 \% e e .{ }^{42} \mathrm{~A}$ related lactone, $(R, Z)$-9-octadecen-4-olide (micromolide, 40$)$ is the female sex pheromone of a stem sawfly, the currant stem girdler, Janus integer (Hymenoptera), ${ }^{\mathbf{4 3 , 4 4}}$ which was synthesized using various methods with a maximum of $96 \% e e .^{37,44-46} \mathrm{~A}$ very efficient synthesis of pure enantiomers of $\gamma$ - and $\delta$-lactones such as $\mathbf{4 0}$ uses enantiomerically pure epoxides $e . g$. 38 obtained by Jacobsen kinetic resolution. Nucleophilic epoxide opening, and lactone formation by $\mathrm{OsO}_{4}$ /oxone oxidation, followed by Lindlar hydrogenation lead to five- or six-membered lactones (Fig. 6). ${ }^{47}$

In the scent marking fluid of the bengal tiger, containing about 120 components, lactones are an important class of constituents. ${ }^{48}$ The lipophilic secretion contains a homologous series of $\gamma$ - and $\delta$-lactones ranging from $\mathrm{C}_{5}$ to $\mathrm{C}_{18}$, missing some odd numbered members. Stereochemical investigations of individual samples showed that the $\delta$-lactones were enantiomerically pure $R$-enantiomers, in some cases accompanied by few percent of the opposite enantiomer. In contrast, the $\gamma$ lactones showed a wider variation, ranging from pure $R$-enantiomers to almost racemic samples. The only unsaturated lactone present was $(S, Z)$-6-dodecen-4-olide (35), which together with decan-5-olide, 4-dodecanolide (34) and 5-dodecanolide, represent major constituents of the secretion. It has been reported that the tiger responds with overmarking when presented to the scent of lactones $\mathbf{3 4}$ and 35, a mixture containing these and other lactones, as well as other components like ketones, or to the perfume Elle (Paco Rabanne). ${ }^{48}$ Lactone 35, a regioisomer of $\mathbf{3 1}$, has been found also in the Roseobacter bacterium producing the latter. ${ }^{34}$ A $89: 11 R-S$ mixture of 35 is the major constituent of the tarsal hair tuft of the black-tailed deer, Odocoileus columbianus. ${ }^{49}$ Racemic 35 as well as the enantiomers induce a typical sniffing and licking behaviour of the deers, but shorter than the original secretion which is composed of a complex compound bouquet. ${ }^{49}$ Lactone 35 is also a major constituent of the marking fluid secreted by the bontebok, Damaliscus dorcas dorcas, a strongly territorial animal. ${ }^{\mathbf{5 0}}$ It occurs as pure $S$-enantiomer. ${ }^{51}$ The lactone is of special interest because of its buttery flavour. It can be produced by whole cell systems from linoleic acid via hydration and chain shortening of 10-hydroxyoctadec-12-enoic acid, ${ }^{52}$ but has also been synthesized repeatedly in an enantiomerically pure form.

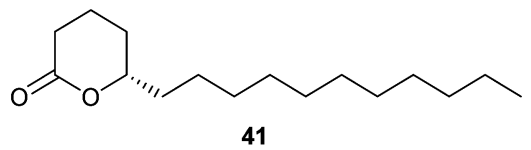

A pheromone of the Oriental hornet, Vespa orientalis, which stimulates workers to construct queen cells, has been identified as $(S)$-5-hexadecanolide (41). ${ }^{53}$ It has been frequently synthesized as discussed elsewhere. ${ }^{54}$ Enantioselective approaches with high $e e$ were recently reported using either an enzymatic approach with alcohol dehydrogenase to form 6-hepten-5-olide, followed by metathesis and hydrogenation, ${ }^{55}$ or by stereoselective formation of pentadec-en-4-ol via aldehyde aminooxylation and a RCM strategy. ${ }^{54}$

Hydroxylated lactones are used by several insects. The males of the jewel wasp, Nasonia vitripennis, a parasitoid of flies, produce a mixture of $(4 R, 5 R)$ - and $(4 R, 5 S)$-5-hydroxy-4-decanolide (46) as a sex pheromone, ${ }^{56}$ which is deposited on surfaces. ${ }^{57}$ The male pheromone dose serves as an indicator of full sperm load, favouring acceptance by the female. ${ }^{58,59}$ The biosynthesis of the pheromone, investigated by feeding various labeled fatty acids, starts from oleic acid (42) that is
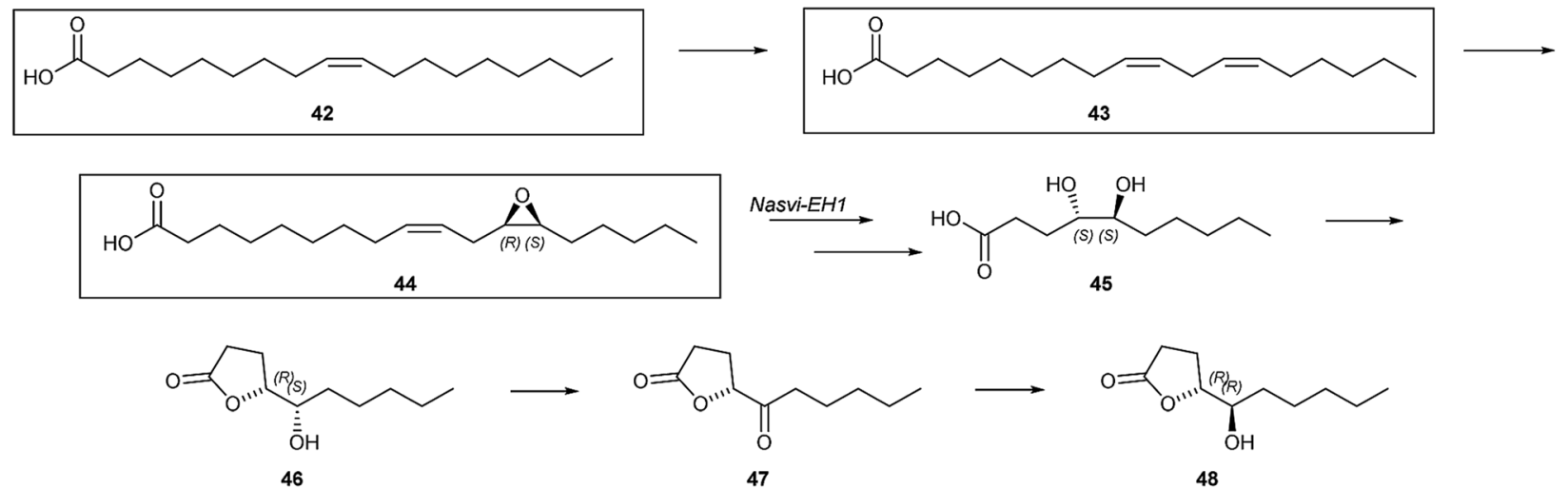

Fig. 7 Proposed biosynthesis of hydroxylactones 46 and 48 . The boxed compounds have been established as precursors by feeding of deuterated compounds. 
transformed into linoleic acid (43), a rare transformation in animals (Fig. 7). ${ }^{60}$ Epoxidation then leads to vernolic acid (44) which is opened by the epoxide hydrolase Nasvi-EH1, established using RNAi technology. ${ }^{61}$ Investigation of other Nasonia species and the closely related Trichomalopsis sarcophagae revealed that all produce 46, but only $N$. vitripennis additionally produces the diastereomer $48 .^{62}$ Most likely, epoxide opening and chain shortening lead to a precursor acid as $\mathbf{4 5}$ that cyclises to 46, although the stereochemistry and mechanism of this conversion is currently unclear. $N$. vitripennis then can epimerize 46 to 48 via a redox sequence. ${ }^{62}$

A recent enantioselective syntheses yielding 46 with $99 \%$ ee uses an enantioselective epoxidation with Shi's catalyst of $(Z)-4$ decenoic acid. ${ }^{63}$

Males of the danaine butterfly Idea leuconoe contain lactones 49 and 50 in their scent gland secretion. ${ }^{\mathbf{1 4}}$ The major $\gamma$-lactones, 49, function as synergists in the sex pheromone and enhance activity. They are produced exclusively as pure enantiomers in a $S, S$-configuration. ${ }^{64,65}$ The related $\delta$-lactones are formed in minor amounts as mixtures of all four enantiomers in varying ratios by individual butterflies. ${ }^{16}$ The chain length distribution is not in accord with the usual fatty acid $\beta$-oxidation mechanism leading to a series of bishomologues. Instead, homologues occur. The oxidation has to take place late after chain length establishment, followed by opening of an 1,2-dioxane or oxetane ring, but no investigation of the biosynthesis has been performed. A 12 step synthesis of both the major 49 and 50 compounds using Prinscyclization and ring-closing-metathesis have been published, starting from enantiomerically pure benzyl glycidyl ether. ${ }^{66}$

Formal cyclization products of $\mathbf{4 9}$ are the so called Hagens's gland lactones 51 and 52 identified from the mentioned gland present in males of parasitic braconid wasps of the genus Diachasmimorpha and Fopius. ${ }^{67,68}$ The glands also contain the simple $\gamma$-lactones 4-octanolide and 34. The function of the gland is not clear, but it has been implicated in mating and/or defense. ${ }^{67,59}$ These lactones have been synthesized more than 15 times, ${ }^{69,70}$ although the interest of synthetic chemists does not square with the ecological importance of the compounds.

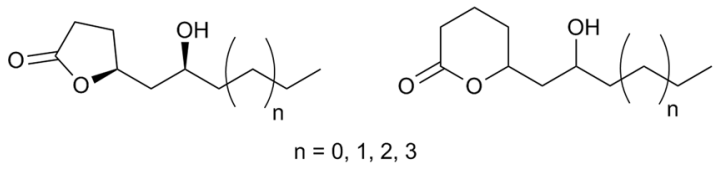

49

50

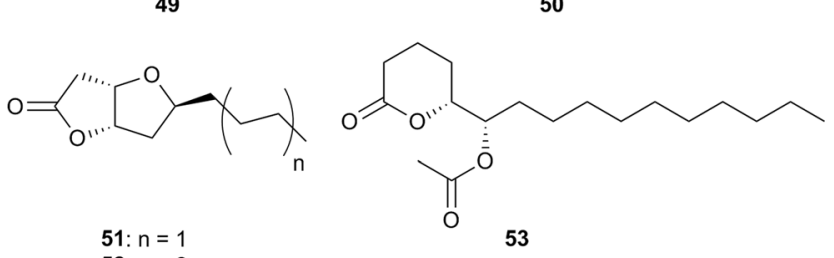

A related acetoxylated lactone is $(5 R, 6 S)$-6-acetoxy-5-hexadecanolide (53), serving as an oviposition marking pheromone of the mosquito Culex quinquefasciatus. ${ }^{71,72}$ Culex mosquitoes are important vectors for human diseases such as the West Nile virus or filariasis. The crystal and solution structures of the complex of the pheromone with the odorant-binding protein
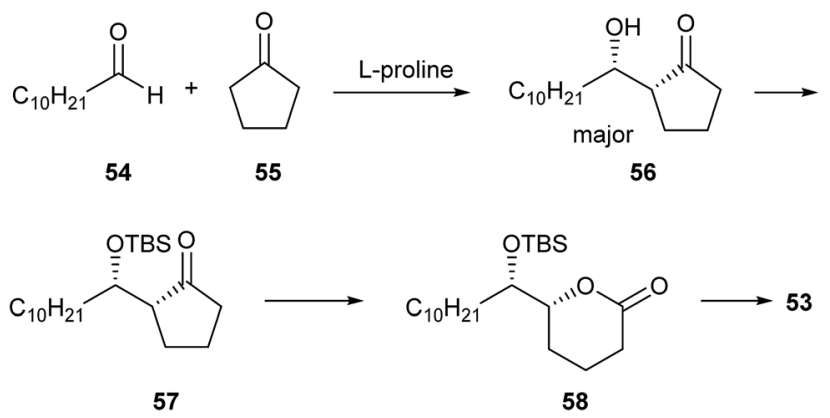

Fig. 8 Synthesis of 53 according to $\mathrm{Li}^{74}$

CquiOBP1 of C. quinquefasciatus has been reported. ${ }^{73}$ The binding motif is different from those of other OBP (odorantbinding protein) pheromone binding motifs, using both a small central cavity for the lactone head group and a long hydrophobic channel for its tail. ${ }^{73}$

Several enantioselective syntheses of $\mathbf{5 3}$ have been published in recent years. An organocatalytic approach using a L-proline catalysed asymmetric aldol reaction followed by Baeyer-Villiger oxidation seems particularly effective, yielding the lactone in 96\% ee (Fig. 8). ${ }^{74}$ The aldol product 56 is isolated as the major diastereomer and transformed via Baeyer-Villiger oxidation in a short sequence into 53. Another synthesis uses a long chain alkynol and transforms it into a dihydroxy acid as the lactone precursor, using epoxidation with Shi's catalyst or Sharpless dihydroxylation to access the various stereoisomers of 53. The obtained $e e$ ranges between 95 and $98 \% .{ }^{75}$ A longer sequence started from $\delta$-gluconolactone, but no chromatographically determined $e e$ was reported.$^{76}$ A very high optical purity ( $e e$ 99\%) was achieved by Singh and Guiry who used kinetic resolution by Sharpless epoxidation as a key step. ${ }^{77}$

One component of the queen pheromone of the fire ant, Solenopsis invicta, is represented by the lactone $59 .^{78}$ The related lactone 60 is a recruitment pheromone positioned on trails of the myrmicine ant Pristomyrmex pungens. ${ }^{79}$ Both lactones originate from the poison gland of the ants and are also produced by Trichoderma soil fungi. ${ }^{80}$ They have been synthesized efficiently by gold-catalysed coupling of terminal alkynes with propiolic acid as a key step. ${ }^{80}$

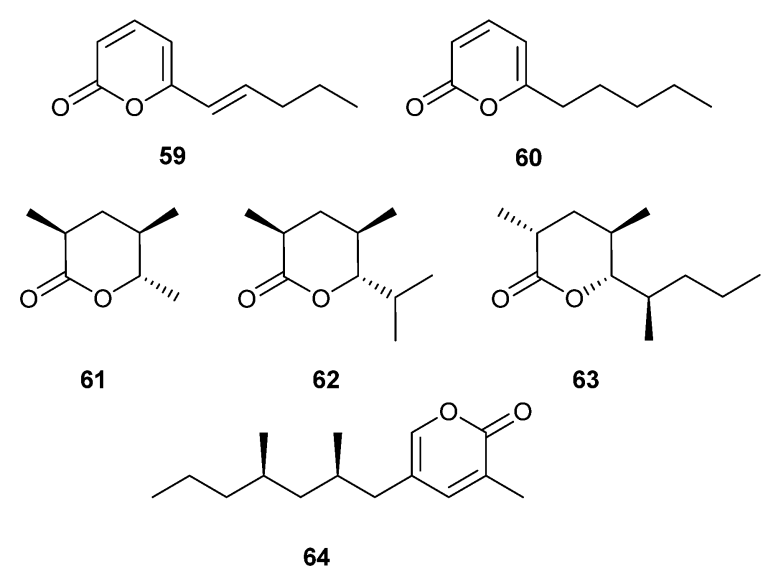


Several other ant pheromones are highly branched $\delta$ lactones. Invictolide, $(2 S, 4 R, 5 S)$-2,4-dimethyl-5-hexanolide (61), is a trail pheromone of carpenter ants of the genus Camponotus $^{\mathbf{8 1 - 8 3}}$ It was synthesized using Baker's yeast reduction of ethyl methylacetoacetate as a key step. ${ }^{82}$ The lactone has also been identified together with some homologues in male Lasius niger heads, but with $(2 R, 4 R, 5 S)$-stereochemistry. ${ }^{84}$ Feeding experiments with deuterated propionate revealed that the methyl groups of 61 originate from two methylmalonate chain extensions of an acetate starter unit. ${ }^{85}$ Four propionate units are used for the biosynthesis of invictolide (63) ${ }^{85}$ Combined with 59 it represents the queen pheromone of the fire ant Solenopsis invicta. ${ }^{78}$ The absolute configuration differs from that of $\mathbf{6 1}$ at C$2 .^{86-88}$ The 2,4,6-epimer of 63 has been reported as a metabolite of the marine actinomycete Nocardiopsis tangguensis. ${ }^{89}$

Recent syntheses of invictolide use a stereospecific oxoniaCope rearrangement, ${ }^{90}$ a relatively lengthy procedure with desymmetrisation of a bicyclic olefin as the core element, ${ }^{91}$ and finally the Roche ester as source of chirality, diastereoselective reduction and enantioselective iridium catalysed hydrogenation as key reactions. ${ }^{\mathbf{9 2}}$

Females of the brownbanded cockroach, Supella longipalpa, attract males with supellapyrone (64).$^{93}$ The pheromone is active over several meters in doses as low as $3 \mathrm{pg} .{ }^{\mathbf{9 4}}$ Researchers should therefore be careful when carrying the synthetic material in public (C. Schal, personal commun.). The $2 R, 4 R$-enantiomer is the naturally produced compound and the most active stereoisomer; ${ }^{95,96}$ the $2 S, 4 R$-enantiomer is also active, but in higher doses. ${ }^{94}$ All four stereoisomers were prepared by Mori et al. using Lipase AK to separate diastereomeric mixtures of symmetrical diols as the key reaction. ${ }^{97}$

\section{Larger macrocyclic lactones}

Seven- to nine-membered lactones have not yet been reported in chemical communication systems employing small molecules, however, 10-membered rings are known in the chemical communication of Anuran amphibians (frogs) which have been studied intensively. ${ }^{\text {98-100 }}$ Mantelline frogs from Madagascar possess femoral glands on their hind legs that disseminate volatile compounds. These volatiles can influence the behaviour of the females, inducing increased motility and movement towards the odour source, thus serving as pheromones although the exact function is not yet known. ${ }^{101}$

Poth et al. have found a series of macrocyclic lactones as pheromones in male mantellines. ${ }^{\mathbf{1 0 1 , 1 0 2}}$ In the femoral glandular extracts of Mantidactylus multiplicatus, M. femoralis and M. betsileanus the macrolides $(S)$-phoracantholide $\mathrm{J}(66)$ and $(S)$ phoracantholide I (65) were identified, which are also found in Australian Phoracantha synonyma beetles. The beetle lactones possess the opposite $R$-configuration and are reported to act as defensive compounds. ${ }^{103}$ A short enantioselective synthesis using the Corey/Nicolaou macrolactonization method as a key step was established (Fig. 9). The alcohol 71 was prepared by the reaction of homoallylmagnesium bromide with $(S)$-propylene oxide. Oxidation of the double bond under Lemieux-Johnson conditions furnished aldehyde 72, which yielded the $Z$ -

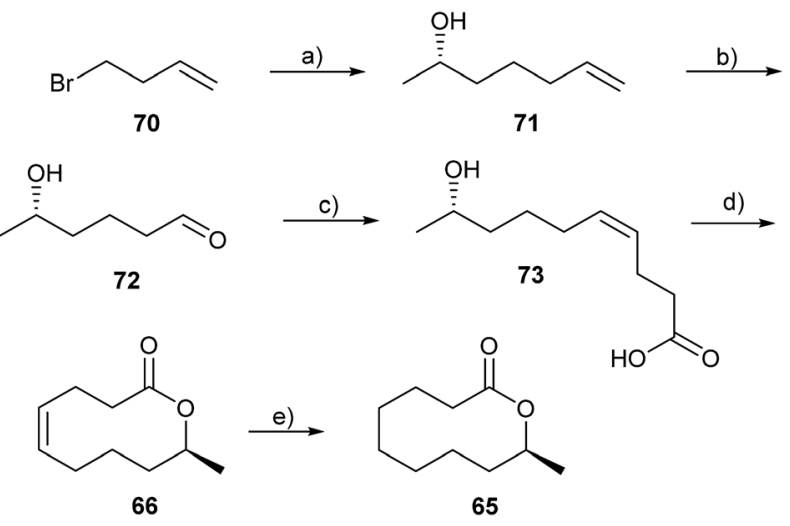

Fig. 9 Synthesis of (S)-phoracantholide I (65) and (S)-phoracantholide J (66). ${ }^{101}$ (a) $\mathrm{Mg}, \mathrm{CuCN}$, (S)-propylene oxide; (b) $\mathrm{K}_{2} \mathrm{OsO}_{4}, \mathrm{NalO}_{4}$; (c) $\mathrm{NaHMDS},\left[\mathrm{Ph}_{3} \mathrm{P}\left(\mathrm{CH}_{2}\right)_{3} \mathrm{COOH}\right] \mathrm{Br}(Z: E=95: 5)$; (d) dipyridyl disulfide, $\mathrm{AgClO}_{4} ;(\mathrm{e}) \mathrm{H}_{2}, \mathrm{Pd} / \mathrm{C}$.

configured hydroxy acid 73 upon a Wittig reaction. Cyclization produced (S)-66 which yielded $(S)-65$ after hydrogenation. Several other approaches to 66 and 65 have been reported. ${ }^{101}$

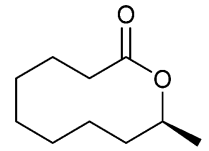

65

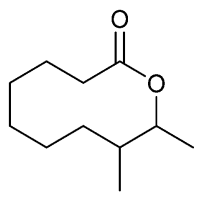

68<smiles>C[C@@H]1CCC/C=C\CCC(=O)O1</smiles>

66

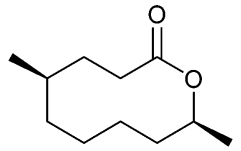

67
Another major component in the glandular extracts of $M$. femoralis is $(4 R, 9 S)$-4-methyldecan-9-olide (mantidactolide A, 67). ${ }^{102}$ In addition to 67 , the macrocyclic lactone 8-methyl-9decanolide (mantidactolide B, 68) is produced by M. femoralis. Two phenotypes exist: one using a mixture of 65 and 67, the other 68 and several secondary alcohols. Individual analysis of M. femoralis males from different locations and genetic analysis of their degree of relationship did not give clear patterns as to whether these phenotypes depend on patterns like genetic relatedness, diet or location. ${ }^{\mathbf{1 0 2}}$ Although the femoral gland constituents are mostly different among related species, macrolides, varying in size, are the predominant compounds.

The lactones are biosynthetically most likely derived from fatty acids that are oxidized in the $\omega-1$ position. The methyl branch is formed by incorporation of methylmalonate instead of malonate during the biosynthesis. ${ }^{104}$ The synthesis of 67 started from (+)-citronellene (74). Epoxide 75 was received after selective epoxidation of the higher substituted double bond. Periodate cleavage and oxidation to chiral acid 76 was followed by esterification with alcohol 77 . The unsaturated ester 78 was submitted to a ring closing metathesis (RCM) reaction, followed by hydrogenation to form the desired macrolide 67 (Fig. 10). ${ }^{102}$ 
<smiles>C=C[C@H](C)CCC=C(C)C</smiles>
$\stackrel{\text { a) }}{\longrightarrow}$

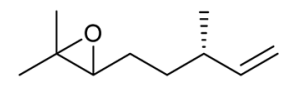

74<smiles>C=CCC[C@@H](O)C=C[C@H](C)CCC(=O)O</smiles>

76<smiles>C=CCC[C@H](C)OC(=O)CC[C@H](C)C=C[Hg]</smiles>

78

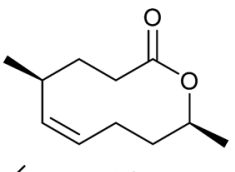

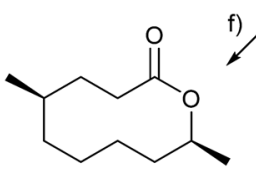

67
Fig. 10 Synthesis of mantidactolide A (67). ${ }^{102}$ (a) $m \mathrm{mCPB}$; (b) $\mathrm{NalO}_{4}$; (c) $\mathrm{CrO}_{3}$; (d) EDC. $\mathrm{HCl} \mathrm{l}$; (e) Grubbs II catalyst; (f) $\mathrm{H}_{2}, \mathrm{Pd} / \mathrm{C}$.

In the glandular extracts of male Gephyromantis boulengeri, another mantelline species, only one major component, gephyromantolide A (69), was present. ${ }^{101}$ Identification via NMR was possible with the content of one single gland. The macrocyclic lactone 69 showed typical terpenoid branching, however, one carbon is missing compared to sesquiterpenes and it therefore might be biosynthetically formed via the fatty acid pathway. Gephyromantolide A was synthesized using RCM as the key step (Fig. 11). The precursor ester $\mathbf{8 4}$ is accessible by coupling of bromoester $\mathbf{8 0}$ with 2-propenylmagnesium bromide to yield ester 81, which was transformed to the chiral acid 82 in good yield and excellent selectivity (ee 99\%) using Evans methodology. Compound 82 and alcohol 83 were coupled to arrive at the macrolide precursor $\mathbf{8 4}$. Several RCM catalysts were tried, but the best results were obtained in the presence of $\mathrm{C}_{6} \mathrm{~F}_{6}$ with a Stewart-Grubbs catalyst in refluxing toluene. A difficultto-separate mixture of compounds including the $E$ and $Z$<smiles>[B]CCCCC(=O)OCC</smiles>

80 a)<smiles>C=C(C)CCCCC(=O)OCC</smiles>

81<smiles>C=C(C)CCC[C@H](C)C(=O)O</smiles>

82<smiles>C=CCC[C@H](C)CO</smiles>

83

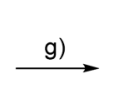<smiles>C1CCCCC1</smiles><smiles>COC(C)=O</smiles><smiles>C=CCCCCC=O</smiles><smiles>C=CCCC</smiles>

Fig. 11 Synthesis of gephyromantolide $A$ (69). Reagents and conditions: (a) $\mathrm{Li}_{2} \mathrm{CuCl}_{4}$, isopropenylmagnesium bromide; (b) $\mathrm{KOH}$; (c) $\mathrm{SOCl}_{2}$; (d) (S)-4-phenyloxazolidin-2-one, nBuLi; (e) NaHMDS, Mel; (f) $\mathrm{KOH}$; (g) $\mathrm{EDC} \cdot \mathrm{HCl}$; (h) Stewart-Grubbs catalyst II, $\mathrm{C}_{6} \mathrm{~F}_{6}$, toluene. isomers as well as smaller ring products was obtained. Isolation by semi-preparative HPLC afforded pure $69 .{ }^{101}$

A suite of macrocyclic lactones containing 11- to 14membered rings, called cucujolides, has been discovered by Oehlschlager et al. in economically important grain beetles of the superfamily Cucujoidae, genera Cryptolestes (Laemophloeidae) and Oryzaephilus (Silvanidae). ${ }^{\mathbf{1 0 5}}$ These macrolides act as aggregation pheromones and are attractive for both males and females of the respective species. (Z)-3-Dodecen-11-olide (ferrulactone II, cucujolide II, $S$-85) and the terpenoid macrolide 155 (see below) constitute the sex pheromone of the male rusty grain beetle, C. ferrugineus. ${ }^{\mathbf{1 0 6}}(Z)$-Tetradec-5-en-13-olide (cucujolide III, 86) is used in the $S$-configuration by $C$. pusillus and in a $33: 67 R-S$-mixture by the flour mill grain beetle, $C$. turcicus. The merchant grain beetle $O$. mercator emits $(3 Z, 6 Z, 11 R)-3,6$ dien-11-olide (cucujolide IV, 87) while $(5 Z, 8 Z, 13 R)$-tetradeca-5,8dien-13-olide (cucujolide $\mathrm{V}, \mathbf{8 8}$ ) is used by $O$. surinamensis and also, in a $85: 15 R-S$ mixture, by $C$. turcicus. Macrolides $(Z)$ dodec-3-en-12-olide (cucujolide VIII, 89) and (3Z,6Z)-dodeca-3,6dien-12-olide (cucujolide IX, 90) were reported as pheromones produced by $C$. pusillus. ${ }^{\mathbf{1 0 7}}$ The earlier work has been reviewed. ${ }^{\mathbf{1 0 5 , 1 0 8}}$

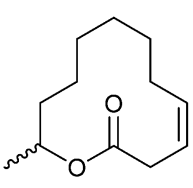

85

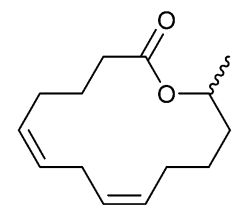

88

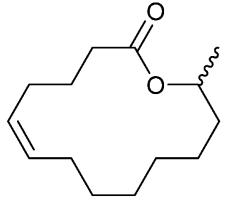

86

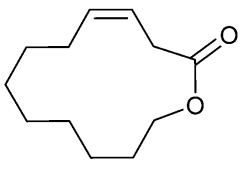

89

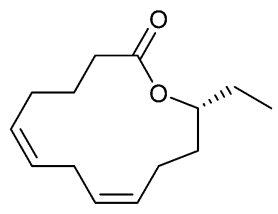

91

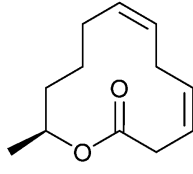

87

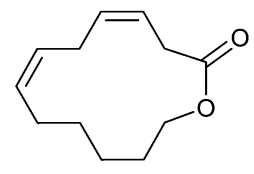

90
Recently, a new cucujolide, $(5 Z, 8 Z, 12 R)$-tetradeca-5,8-dien12-olide (cucujolide $\mathrm{X}, \mathbf{9 1}$ ), was identified and shown to induce attraction of both sexes of the sawtoothed grain beetle, Oryzaephilus surinamensis, ${ }^{109}$ which is one of the most common pests in stored grain. ${ }^{\mathbf{1 1 0}}$

The biosynthesis of these pheromones has been examined in the rusty grain beetle, $C$. ferrugineus and in the merchant grain beetle, $O$. mercator, using radiolabeled precursors. ${ }^{\mathbf{1 0 8}}$ The biosynthesis of 85 starts from oleic acid (42), followed by three cycles of $\beta$-oxidation to acid 92, and hydroxylation at the $\omega-1$ carbon atom to precursor 93. Cyclization to 85 proceeds with retention of the configuration (Fig. 12), as evidenced by ${ }^{2} \mathrm{H}$ and ${ }^{18} \mathrm{O}$ labelling studies. Intermediates $\mathbf{9 2}$ and 93 were 
<smiles>CCCCCCCC/C=C/CCCCCCCC(=O)O</smiles>

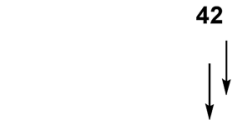<smiles>CCCCCCCC/C=C/CC(=O)O</smiles>

92<smiles>CC(O)CCCCCC/C=C/CC(=O)O</smiles><smiles>C[C@@H]1CCCCCC/C=C\CC(=O)O1</smiles>

85

Fig. 12 Biosynthesis of cucujolide II (85) supported by feeding experiments with labeled precursors 42,92 , and $93 .{ }^{111}$

incorporated when fed to the beetles, while lauric and 11hydroxydodecanoic acids were not effective. ${ }^{111}$ Various radiolabeled fatty acids such as palmitic, oleic, and linoleic acids where incorporated into the various cucujolides, pointing to a similar biosynthesis for all cucujolides. ${ }^{\mathbf{1 0 8}}$
Cucujolides have been synthesized as $R$ - and $S$-enantiomers and also in racemic form. The synthetic strategy is based on the formation of an acyclic hydroxycarboxylic acid precursor, followed by macrolactonization ${ }^{\mathbf{1 1 0 , 1 1 2 , 1 1 3}}$ or by enzymatic macrolactonization. ${ }^{\mathbf{1 1 4}}$ Ferrulactone I and ferrulactone II were synthesized by Cheskis et al., ${ }^{\mathbf{1 1 5}}$ using a sigmatropic rearrangement of activated allyl sulfides. The emergence of RCM allowed new strategies to be employed. ${ }^{109}$ The ring-closing alkyne metathesis (RCAM) of an enyne precursor served as the key step in the synthesis of 91 (Fig. 13). The stereogenic centre was established by a Kobayashi enantioselective diethylzinc alkylation in 99\%ee. Compounds $\mathbf{9 7}$ and $\mathbf{9 8}$ were coupled in a highly stereoselective Wittig reaction, followed by saponification to acid 99. Subsequent esterification yielded diynoate 96 which was submitted to RCAM which does not affect the double bonds. The imidazolin-2-iminato tungsten alkylidyne complex 101 was used at room temperature. ${ }^{\mathbf{1 1 6 - 1 1 8}}$ The macrolide 100 could be isolated in good yield, which furnished the target compound 91 after hydrogenation with a Lindlar catalyst with an $e e$ of $99 \%$. A similar approach to $R \mathbf{- 8 8}$ led to the product with an $e e$ of $33 \%$ because of the known lower enantioselectivity of dimethylzinc compared to diethylzinc in the Kobayashi addition. $^{\mathbf{1 1 9}}$

Cucujolide VIII, $(Z$ )-dodec-3-en-12-olide (89), is also a female produced pheromone of the emerald ash borer, Agrilus planipennis, which is an invasive palearctic species that has killed million of ash trees in Canada and the USA. ${ }^{\mathbf{1 2 0}}$ Recently, Mayo et al. published a concise, three step synthesis of $89 .{ }^{121}$ The synthesis (Fig. 14) started from 10-bromo-1-decene which was transformed into the aldehyde $\mathbf{1 0 2}$ and coupled in a lithium-

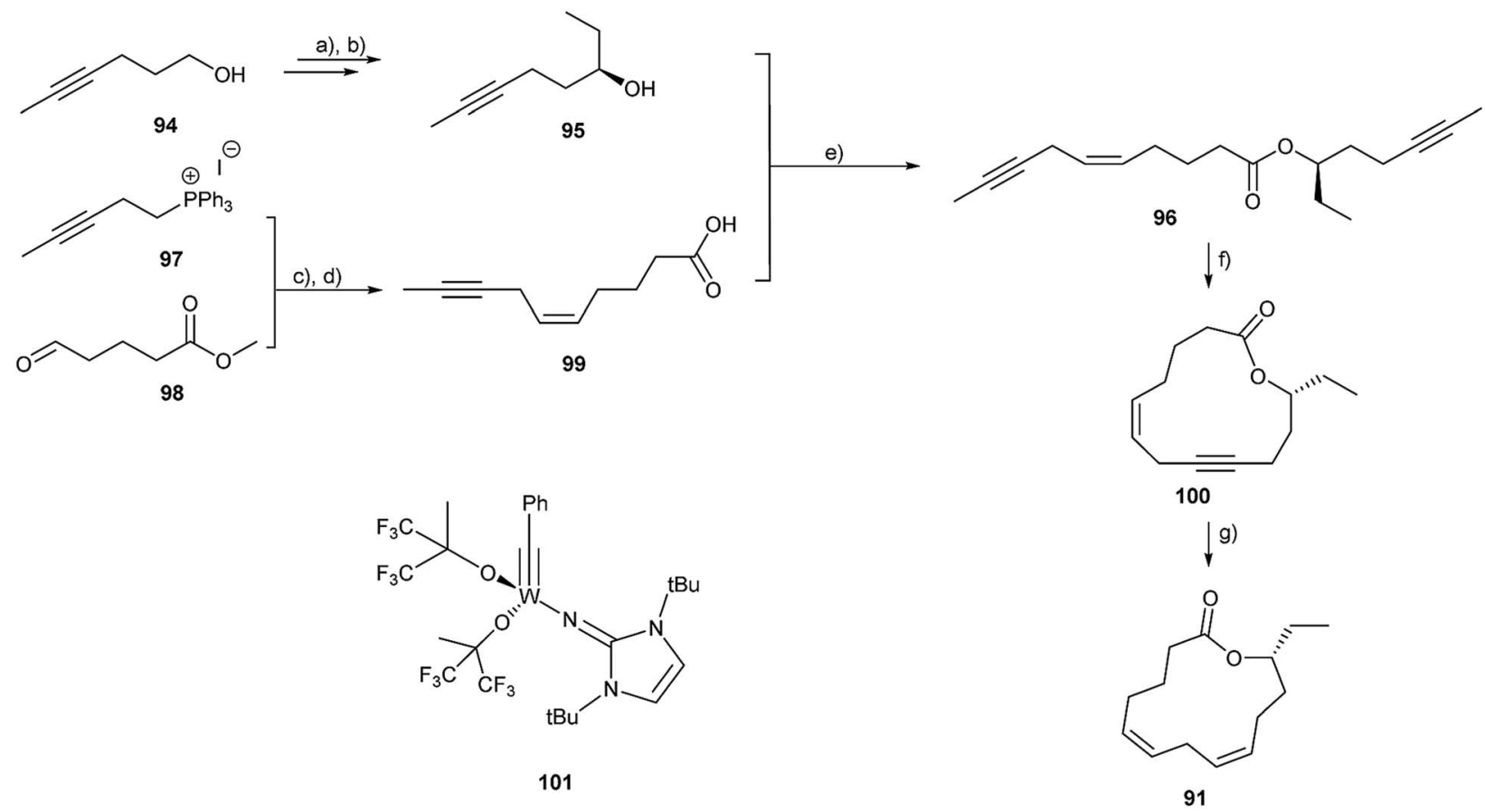

Fig. 13 Synthesis of $(5 Z, 8 Z, 12 R)$-tetradeca-5,8-dien-12-olide (91). ${ }^{109}$ (a) oxalyl chloride; (b) N,N-cyclohexane-1,2-diyl-bis-(1,1,1-tri-

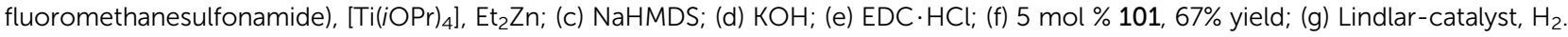



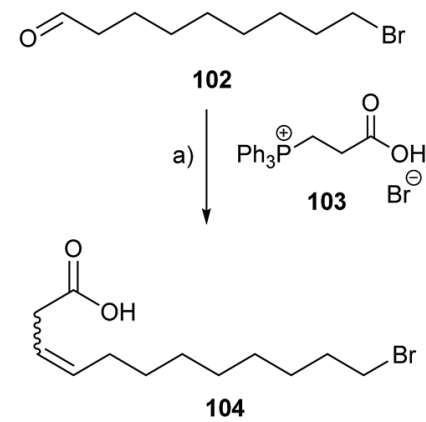

b) $\downarrow$

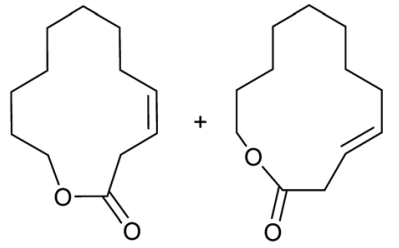

$89 \quad 2: 1^{105}$

Fig. 14 Synthesis of (Z)-dodec-3-en-12-olide (89). (a) NaHMDS; (b) $\mathrm{K}_{2} \mathrm{CO}_{3}, \mathrm{KI}$.

salt-free Wittig reaction with 103 to form bromoacid 104. The key step was the intramolecular $\mathrm{S}_{N} 2$ esterification of $\mathbf{1 0 4}$ using potassium carbonate as the base and potassium iodide as the promoter in refluxing acetone. The reaction yielded, however, an inseparable $2: 1$ mixture of $(Z)$-dodec-3-en-12-olide (89) and $(E)$-dode-3-en-12-olide (105) with an overall yield of $57 \%$. Fortunately, both macrocyclic lactones were active against the ash borer, so the blend of $2: 1$ had the potential to be a detection, mating disruptor or mass trapping agent, which could be used in emerald ash borer control.

A related macrocyclic lactone, parcoblattalactone (110), is a sex pheromone of the broad wood cockroach, Parcoblatta lata, ${ }^{\mathbf{1 2 2}}$ found in the pine forests of southeastern USA. The 13-

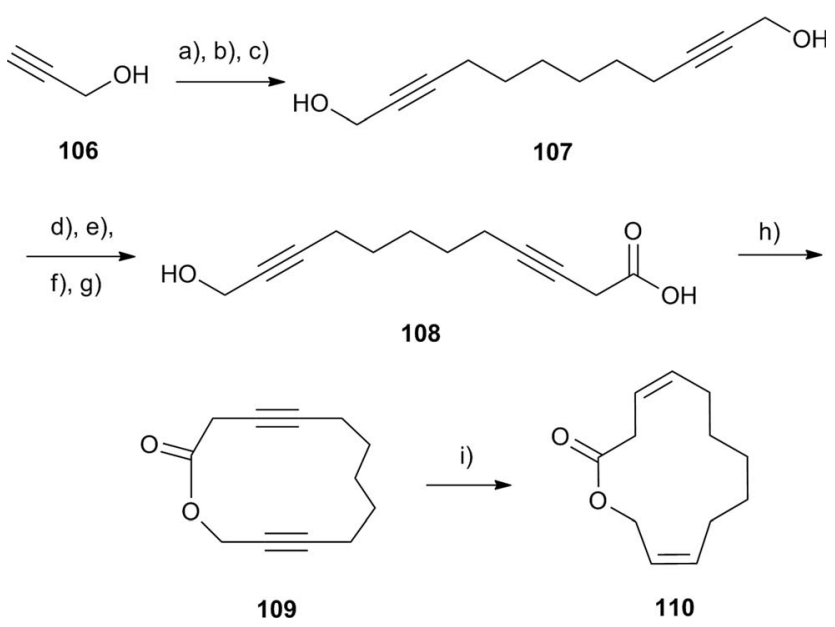

Fig. 15 Synthesis of $(3 Z, 10 Z)$-dodecadienolide (parcoblattalactone, 110). (a) Dihydropyrane; (b) $n$-BuLi, 1,6-dibromohexane; (c) $\mathrm{HCl}$,

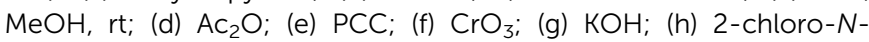
methylpyridinium iodide, $\mathrm{Et}_{3} \mathrm{~N}$; (i) P-2-nickel, $\mathrm{H}_{2}$. membered (3Z,10Z)-dodeca-3,10-dienolide (110) was synthesized by cyclization of the diyne precursor 108 and subsequent hydrogenation (Fig. 15). The synthesis took advantage of the symmetric placement of the double bonds and the oxygen atoms. The key step was the deconjugation of one triple bond to furnish carboxylic acid $\mathbf{1 0 8}$, followed by macrolactonization and Lindlar hydrogenation. The overall yield was $4 \%$.

Major components in the scent gland extracts of the male longwing tropical butterflies Heliconius pachinus and H. cydno are the macrolides $(9 Z, 11 E, 13 S)$-octadeca-9,11-dien-13-olide (111, $S$-coriolide), (9Z,11E,13S,15Z)-octadeca-9,11,15-trien-13olide (112), (9Z,13S)-octadec-9-en-13-olide (113) and $(9 Z, 11 S)$ octadec-9-en-11-olide (114). ${ }^{123}$ Obviously, these macrolides are biosynthetically derived from oleic, linolenic and linoleic acid by internal oxidation, probably by lipoxygenases, and might play a role in the chemical communication system of $H$. cydno and $H$. pachinus.

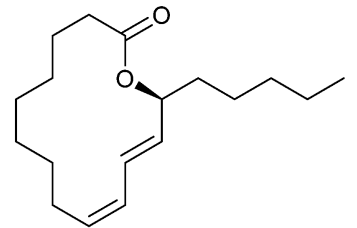

111<smiles>CCCCC[C@H]1C/C=C\CCCCCCCC(=O)O1</smiles>

113

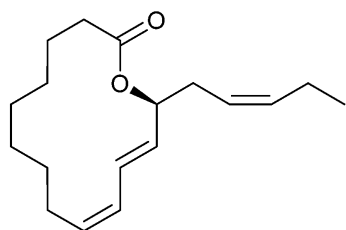

112<smiles>CCCCCCCCC/C=C\[C@@H](CCCCCCC)OC(C)=O</smiles>

114
Coriolide has been earlier isolated from male $H$. pachinus scent glands, but in the opposite $R$-configuration. ${ }^{\mathbf{1 2 4}}$ In this case the absolute configuration was determined via ORD (optical rotatory dispersion) by comparison with a sample obtained of seed oil from Monnina emarginata, a plant native to Uruguay, known to contain $S$-111. The spectroscopic properties of 111 reported in ref. 123 and confirmed by synthesis were identical to those reported for $S$-111. Therefore, the reason for the discrepancy in the reported enantiomer composition of $H$. pachinus remains unclear, but a stereochemical switch in different populations cannot be excluded.

Compounds 111 and 112 have been synthesized enantioselectively using enzymatic oxidation of linoleic acid (43) with soy bean lipoxygenase, reduction with $\mathrm{NaBH}_{4}$ to compound 115 and macrolactonization according to Corey/Nicolaou with an ee of more than 95\% (Fig. 16). ${ }^{123}$ Lactones 113 and 114 were synthesized using RCAM or RCM methods. ${ }^{123}$

$(R)$-15-Hexadecanolide (116) is, together with $\beta$-sesquiphellandrene and methyl $(Z)$-8-hexadecenoate, the attractant pheromone of the soybean stink bug Piezodorus hybneri (Heteroptera: Pentatomidae), which is released by males. Only the full mixture showed optimal attraction, although individual 

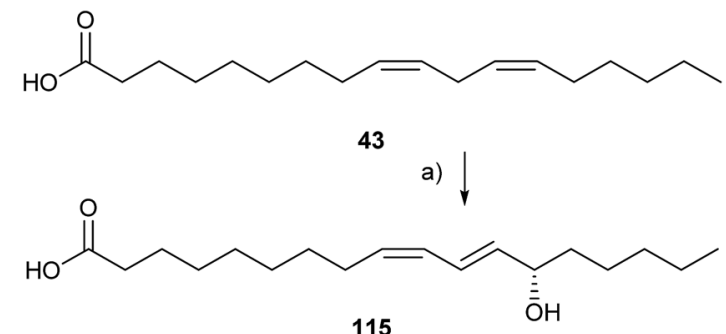

b)

\section{1}

Fig. 16 Synthesis of S-coriolide (111). (a) Soybean lipoxygenase, then $\mathrm{NaBH}_{4} ;\left(\right.$ b) $\mathrm{PPh}_{3},\left(\mathrm{C}_{5} \mathrm{H}_{5} \mathrm{NS}\right)_{2}$, ee $97 \%$.

components such as $\mathbf{1 1 6}$ were attractive in laboratory olfactometer bioassays. ${ }^{125}$ Field experiments showed attraction only in high doses. ${ }^{126}$ Lactone 116 and macrolides 117, 118, and 119 are also constituents of the scent gland secretion of several male Heliconius butterflies, i.e. H. melpomene, together with similar $\omega$ and $\omega-1$ macrolides ranging from $\mathrm{C}_{12}$ to $\mathrm{C}_{20} \cdot{ }^{127,128}$ During copulation these lactones are transferred to the female together with long chain esters and the antiaphrodisiac pheromone ocimene. In this context, the high boiling components may serve as a fixative to prevent the fast evaporation of ocimene from the female's scent pouch. ${ }^{127}$<smiles>C[C@H]1CCCCCCCCCCCCCC(=O)O1</smiles>

Large, unbranched terminally oxidized macrolides, ranging from 16-octadecanolide (117) to 26-hexacosanolide (122) have been identified in the Dufour's gland of various bees. The Dufour's gland ancestral function is cell lining, but a communicative role is derived in some cases. ${ }^{129,130}$ Males of the bee Lasioglossum zephyrum (Halictinae) contain macrolides 118 to 121 as well as some mono-unsaturated derivatives, with an unknown location of the double bonds, in the gland. ${ }^{131}$ Males react towards synthetic macrolides or isolated compound mixtures, and the results inclined the authors to state their function as sex pheromones in this species. In L. malachrum the macrolide composition of the Dufour's gland secretion is similar, and the lactones are also present on the cuticle. It has been suggested that the macrolides function as the dominance signal of queens. ${ }^{\mathbf{1 3 2}}$ Besides 118-121, smaller amounts of the unsaturated analogues 123-130 occur possessing a $Z$-double bond at the $\omega-7$ or the $\omega-9$ position. ${ }^{133,134}$ Lactones $118,119,120,125,126,128$, 129, and 130 proved to be active in electrophysiological assays using coupled gas chromatography/mass spectrometry. ${ }^{130}$ The results showed that large molecules such as the 25 membered ring lactone $\mathbf{1 2 9}$ are volatile enough to serve as a volatile signal. The function of the lactones remains unclear despite several investigations. A function in kin recognition seems highly likely, but evidence is only circumstantial. The biological function of the macrolides in the behaviour of the bees has been discussed by Hefetz. ${ }^{134,130}$ These large macrolides have also been identified from the Dufour's gland of other halictine nearctic bees such as Agapostemon, Augochlora, Augochlorella, Augochloropsis, Dialictus, Evylaeus, Halictus, Nomia ${ }^{\mathbf{1 3 5 - 1 4 0}}$ as well as Hylaeus, ${ }^{\mathbf{1 4 1}}$ Colletes, (Colletidae) ${ }^{\mathbf{1 4 2 , 1 4 3}}$ and Andrena (Andrenidae). ${ }^{\mathbf{1 4 3}}$

Eicosanolide (119) has been synthesized by ring-closing metathesis (RCM) by Fürstner et al. ${ }^{144}$ showing for the first time the importance of RCM for lactone synthesis.

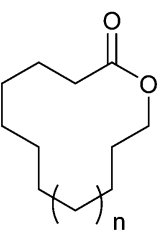

117: $n=6$

118: $n=8$

119: $n=10$

120: $n=12$

121: $n=14$

122: $n=16$

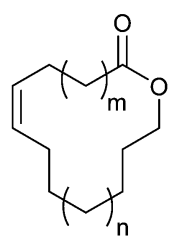

123: $m=6, n=3$

124: $m=8, n=1$

125: $m=8, n=3$

126: $m=10, n=1$

127: $m=10, n=3$

128: $m=12, n=1$

129: $m=12, n=3$

130: $m=14, n=1$
131<smiles>CCOC(=O)C(C)C(C)(O)COC(C)=O</smiles>

132

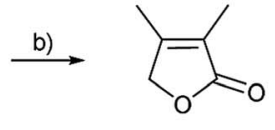

133

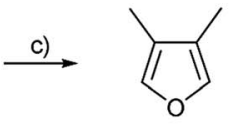

134

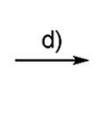

135

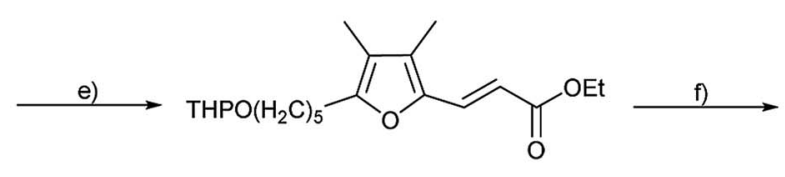

136

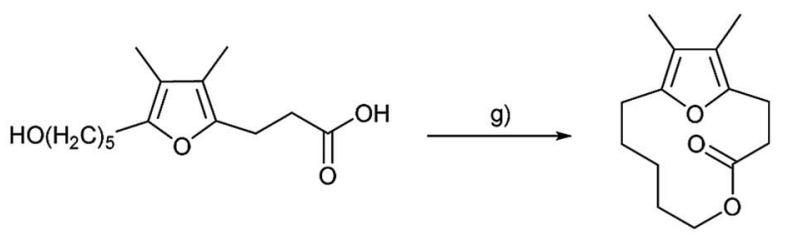

137<smiles>Cc1c(C=O)oc(C=O)c1C</smiles>

Fig. 17 Synthesis of Galerucella furan lactone 138. Reagents and conditions: (a) (i) $\mathrm{CH}_{3} \mathrm{COCl}$, pyridine; (ii) $\mathrm{CH}{ }_{3} \mathrm{CH}(\mathrm{ZnBr}) \mathrm{COOEt}$, diethyl ether; (b) pTsOH, toluene; (c) DIBALH, diethyl ether; (d) (i) BuLi, THF, I( $\left.\mathrm{CH}_{2}\right)_{5} \mathrm{OTHP}$; (ii) BuLi, THF, DMF; (e) triethyl 2-phoshonoacetate, LiOtBu, hexane; (f) (i) $10 \% \mathrm{Pd} / \mathrm{C}$, hexane, $\mathrm{H}_{2}$; (ii) PPTS, EtOH; (iii) $\mathrm{KOH}, \mathrm{MeOH} / \mathrm{H}_{2} \mathrm{O}$; (g) diethyl azodicarboxylate, $\mathrm{PPh}_{3}$, toluene. 
A unique macrolide has been identified as the aggregation pheromone of males of the leaf beetles Galerucella calmariensis and Galerucella pusilla (Coleoptera: Chrysomelidae), produced when feeding on host foliage. ${ }^{\mathbf{1 4 5}}$ These species were imported into the USA for the biological control of purple loosestrife, Lythrum salicaria, a non-native plant that has become an ecologically damaging invasive weed in wetland areas. The compound 12,13-dimethyl-5,14-dioxabicyclo[9.2.1]-tetradeca1(13),11-dien-4-one (138) is a lactone that includes a 3,4-dimethylfurane substructure and is attractive to both sexes of each species. This pheromone is biosynthetically very likely formed from furan fatty acids, common in some plants, ${ }^{\mathbf{1 4 6}}$ by terminal oxidation and chain shortening.

An improved synthetic approach to 138 included the preparation of the 3,4-dimethylfuran ring (134), constructing the hydroxyl and acyl side chains, and closing the lactone ring (Fig. 17). Protected hydroxyacetone formed via a Reformatsky reaction the hydroxyester 132, which furnished lactone 133, under acidic conditions. Conversion into 3,4-dimethylfuran (134) was achieved by a DIBAL reduction. The furan ring was smoothly alkylated and carbonylated to aldehyde 135, which was elaborated to unsaturated ester 136 by HWE condensation. The double bond in the side chain was selectively reduced and the hydroxy and acyl functions were deprotected to form the hydroxy acid 137, which was cyclized under Mitsunobu conditions. ${ }^{147}$

\section{Terpenoid lactones}

Eldanolide (140) is a sex pheromone in the wing gland of the male African sugar-cane borer Eldana saccharina (Lepidoptera), ${ }^{\mathbf{1 4 8 , 1 4 9}}$ a serious pest in African cereal crops. Several syntheses for the natural $(3 S, 4 R)$-isomer and the racemic mixture have been developed. ${ }^{150-155}$ Recently, Devalankar et al. obtained the lactone $\mathbf{1 4 0}$ by a regioselective ring opening of chiral epoxide 139 with Grignard chemistry (Fig. 18). ${ }^{156}$ The enantiomerically pure epoxy ester 139 was obtained by Jacobsen's hydrolytic kinetic resolution with an ee of $96 \%$.

The oxidized monoterpenes $\alpha, \alpha$-acariolide (141) and $\alpha, \beta$ acariolide (142) were identified from the acarid mites, Schwiebea araujoae and Rhizoglyphus sp., respectively. ${ }^{157}$ Both lactones have been synthesized from bromocyclopentanone. ${ }^{157}$ Lactone 142 is also available using a silyloxyfuran strategy. ${ }^{158}$ The related lactone $\beta$-acariolide $(\mathbf{1 4 3})$ is an oil gland secretion product of the mold mite, Tyrophagus putrescentiae. ${ }^{159}$ A semiochemical function of these mite lactones has not been reported yet.

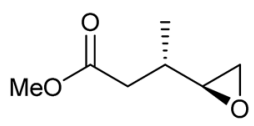

139

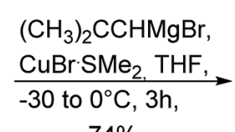

$74 \%$

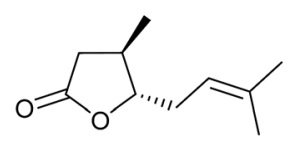

140
Fig. 18 Eantioselctive synthesis of (+)-eldanolide (140).<smiles>CC(C)=CCCC1=CCOC1=O</smiles><smiles>CC(C)=CCC=C1CCOC1=O</smiles>

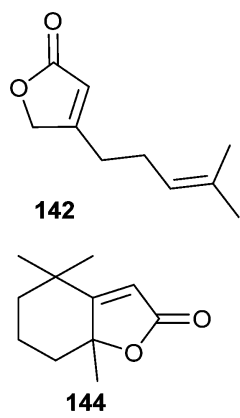

Dihydroactinidiolide (144) is one of the three queen pheromone components isolated from the red imported fire ant Solenopsis invicta. ${ }^{78}$ It also occurs often in male scent secretions of butterflies, e.g. in Idea iasonia, ${ }^{160}$ although its function is unknown in these cases. It is most likely a degradation product of carotenoids. Since the first synthesis of $\mathbf{1 4 4}$ by Sakan et al., ${ }^{161}$ many different syntheses have been reported.

Aphids are the major insect pests of agriculture in temperate regions. Mixtures of iridoids are sex pheromones of many aphid species from the subfamily aphididae. The biology of aphid sex pheromones, the associated chemistry and the biochemistry has been reviewed in detail recently by Pickett $e t$ al. in this journal. ${ }^{162,163}$ The aphid pheromones are usually mixtures of $(4 a S, 7 S, 7 a R)$-nepetalactone (145) and the respective $(1 R, 4 a S, 7 S, 7 a R)$-nepetalactol (146). ${ }^{164-171}$ The pheromone can also act as an attractant for parasitoids of the aphids. ${ }^{172}$ Nepetalactone is commercially available. ${ }^{173} \mathrm{~A}$ method for diastereomer assignment of $\mathbf{1 4 5}$ has been developed. ${ }^{168}$ Both nepetalactone and nepetalactol with unknown stereochemistry are also released by the females of the greenbug, Schizaphis graminum, but only the lactol attracts males. ${ }^{174}$ The damson hop aphid, Phorodon humili, uses the nepetalactol isomers 147 and 148. ${ }^{175}$

Lactone 145 and its enantiomer are powerful cat attractants, ${ }^{176}$ an effect easily visible by the strong attraction of domestic cats to Nepeta plants. The biological reason for this attraction is unknown.

Several parasitoids of aphids use iridoid compounds for communication. The wasp Leptopilina heterotoma is a parasitoid of Drosophila flies. Females secrete $(4 R, 4 a R, 7 R, 7 a S)-(-)$-iridomyrmecin (149) and $(4 S, 4 a R, 7 R, 7 a S)-(+)$-iridomyrmecin (150), while males produce only the latter. ${ }^{177}$ Originally used as a defensive secretion, these compounds also became pheromone signals during evolution. ${ }^{178}$ Lactone $\mathbf{1 4 9}$ alone is used as a nonspecific competition avoidance signal for conspecific and heterospecific parasitoids. Furthermore, in combination with $\mathbf{1 5 0}$ and another, unknown, stereoisomer it acts as a species-specific sex pheromone. ${ }^{178}$ Iridomyrmecin with unknown stereochemistry is also a component of the trail pheromone of the argentine ant, Linepithema humile. ${ }^{179}$ The endohyperparasitoid (parasitoid of the aphid parasitoid Aphidius uzbekistanicus) Alloxysta victrix, releases related volatiles the significance of which in this tetratrophic system are not well understood. The volatiles consist of $(4 S, 4 a R, 7 S, 7 a R)$-iridomyrmecin (151) with $95-97 \% e e$ and stereochemically pure $(4 S, 4 a S, 7 R, 7 a S)$-iridomyrmecin (152) as a minor component. ${ }^{180}$ In contrast to 149 and 150, these diastereomers exhibit a trans-fused lactone ring. As a 
minor component, $(4 R, 4 a R, 7 R, 7 a S)$-dihydronepetalactone (151) occurs as well, again with a trans-fused lactone ring. Enantioselective access to all stereoisomers of iridomyrmecin and dihydronepetalactone starting from limonene via the key intermediate $\mathbf{1 5 4}$ has recently been developed by Francke. Earlier synthesis to these compounds are discussed as well. ${ }^{180,181}$<smiles>CC1=COC(=O)[C@H]2[C@@H](C)CC[C@@H]12</smiles>

145<smiles>C[C@H]1CC[C@H]2[C@H]1COC(=O)[C@@H]2C</smiles>

149<smiles>C[C@H]1CCC2[C@H]1C(=O)OC[C@@H]2C</smiles>

150<smiles>CC(=O)OCC1=C(C)CC[C@@H]1[C@H](C)CO</smiles>

154

153<smiles>CC1=CO[C@@H](O)[C@H]2[C@@H](C)CC[C@@H]12</smiles>

147<smiles>C[C@H]1COC(=O)[C@H]2[C@H]1CC[C@H]2C</smiles>

151

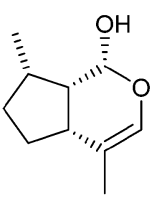

148

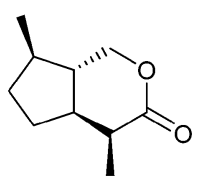

152
The terpenoid (4E,8E)-4,8-dimethyldeca-4,8-dien-10-olide
(ferrulactone I, cucujolide I, 155) is used together with 85 as a (ferrulactone I, cucujolide I, 155) is used together with 85 as a

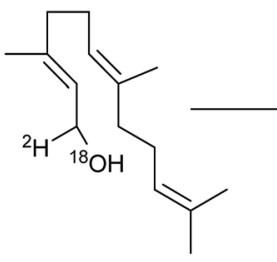

159

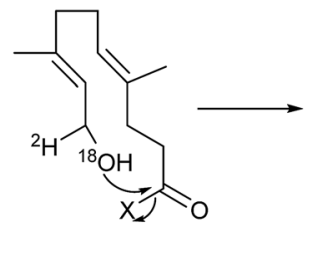

160

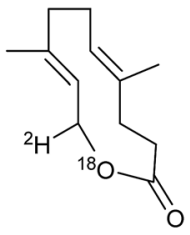

${ }^{1} \mathrm{H},{ }^{18} \mathrm{O}-155$
Fig. 19 Biosynthesis of cucujolide I (155) from (E,E)-farnesol (159, X = a leaving group such as $\mathrm{COA}) .{ }^{111}$ pheromone by male rusty grain beetles, C. ferrugineus (see above). ${ }^{106}$ Feeding experiments with ${ }^{2} \mathrm{H}$ - and ${ }^{18} \mathrm{O}$-labeled farnesol (159) showed retention of the label, determined by GC/MS. ${ }^{111}$ Transformation by the beetle is obviously accomplished through oxidative cleavage of the terminal double bond, followed by cyclization as shown in Fig. 19.<smiles>CCCC=C(C)CCC(=O)OCC=C(C)CC</smiles>

155<smiles></smiles>

156<smiles>C=C[C@]1(C)CCC[C@]2(C)OC(=O)C[C@H]12</smiles>

$(+)-157$<smiles>C=C[C@]1(C)CCC[C@]2(C)OC(=O)C[C@H]12</smiles>

$(+)-158$
Male adult white Pieris butterflies produce aphrodisiac pheromones some days after eclosion, ensuring their mating success. In the small white, $P$. rapae, the macrolide with a small ring-size, ferrulactone I (155), together with phytol and hexahydrofarnesylacetone makes up the pheromone, while in the large white, P. brassicae, $\mathbf{1 5 5}$ is replaced by the larger homologue, brassicalactone (164), carrying an additional isoprene unit, for the same purpose. ${ }^{\mathbf{1 8 2}}$ By application of these mixtures, freshly emerged, unsuccessful males can be transformed into "supermales" with high mating success. ${ }^{182}$ Macrolide 155 has been synthesized starting from geranyl acetate using macrolactonization procedures. ${ }^{182,183}$

The synthesis of closely related $\mathbf{1 6 4}$ was based on a RCM reaction (Fig. 20) that failed for $\mathbf{1 5 5 .}^{\mathbf{1 8 2}}(E, E)$-Farnesyl acetate (161) was converted by periodate mediated terminal double bond cleavage, a Wittig reaction, and reduction to the alkatrienol 162 showing a terminal double bond. Transesterification with $\mathrm{Bu}_{2} \mathrm{SnO}$ yielded the $\mathrm{RCM}$ precursor 163 which was cyclized using a $2^{\text {nd }}$ generation Grubbs catalyst to give a $3: 1$ blend of the diastereomers of the 15-membered macrolide 164 in 50\% yield, separable by chromatography.

An isomer of 155 is $E$,E-suspensolide (156) is, along with anastrephin (157) and epi-anastrephin (158), the key component of sex pheromones released by the males of Anastrepha suspensa and $A$. ludens, the Caribbean and Mexican fruit flies, ${ }^{\mathbf{1 8 4 - 1 8 6}}$ as well as A. fraterculus. ${ }^{187}$ These flies pose a serious threat to fruit<smiles>CC(=O)OC/C=C(\C)CC/C=C(\C)CCC=C(C)C</smiles>

161<smiles>C=CCC/C(C)=C/CC/C(C)=C/COC(=O)CCC(C)=CC</smiles>

163<smiles>C=CCCC(C)=CCCC(C)=CCO</smiles>

162

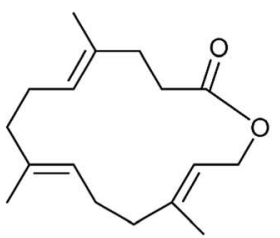

$(E, E, E)-164$

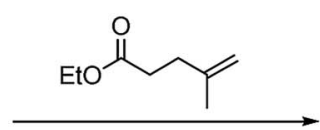

e)

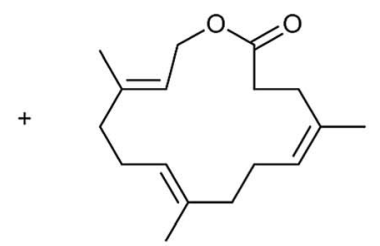

$3: 1$

$(Z, E, E)-164$

Fig. 20 Synthesis of brassicalactone (164). Reagents and conditions: (a) $\mathrm{OsO}_{4} / \mathrm{NMO}$, acetone/ $\mathrm{H}_{2} \mathrm{O}$; (b) $\mathrm{NalO}$, 1,4-dioxane/ $\mathrm{H}_{2} \mathrm{O}$; (c) $\mathrm{MePPh} 3 \mathrm{Br}$, $n$-BuLi, dimethoxyethane; (d) $\mathrm{LiAlH}_{4}$, diethyl ether; (e) $\mathrm{Bu}_{2} \mathrm{SnO}$; (f) Grubbs $2^{\text {nd }}$ generation, $\mathrm{CH}_{2} \mathrm{Cl}_{2}$. 


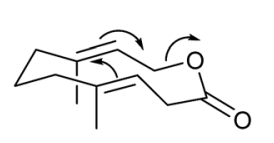

156

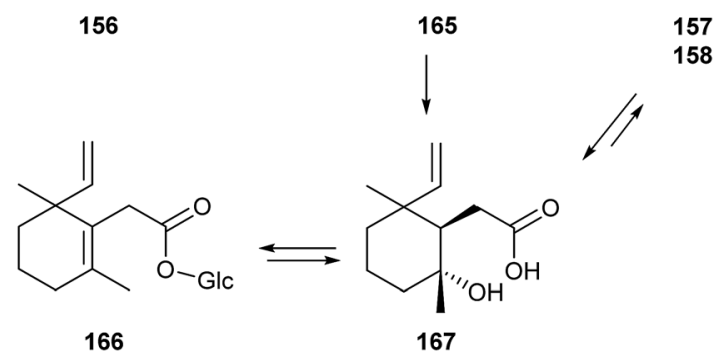

Fig. 21 Interconversion of pheromone components in the oral secretion droplets of male Anastrepha suspensa. ${ }^{189}$

commodities. Macrolide $\mathbf{1 5 6}$ is the likely biosynthetic precursor of both 157 and 158, which are formed via rearrangement. ${ }^{188}$ The latter lactones occur as an almost racemic $55: 45(-) /(+)$ mixture in A. suspensa. ${ }^{189}$ The initial stereochemical assignment has been revised by resolution. ${ }^{190}$ The anastrephin lactones have been repeatedly synthesised in racemic ${ }^{191,192}$ and optically active forms. ${ }^{193-195}$ Suspensolide (156) was prepared by macro lactonization. ${ }^{\mathbf{1 9 0 , 1 9 6 , 1 9 7}}$ Male A. suspensa deposit an oral secretion on the underside of leaves that is highly attractive to conspecific males and females. The major attractive components are 157 and 158. Stereochemistry does not seem to play a role here and 156, present in small amounts only, serves as a biosynthetic precursor. The chemistry going on in the secretion droplets has been examined in detail (Fig. 21), explaining the long activity of these droplets. ${ }^{\mathbf{1 8 9 , 1 9 8}}$ In essence, sugar rich oral secretion droplets are a slow-release formulation for the pheromone. Suspensolide rearranges to the cation $\mathbf{1 5 6}$ which is trapped by water to form acid 167. The trans-fused lactone ring excludes direct formation of lactones $\mathbf{1 5 7 / 1 5 8}$. The acid can be glucosylated to form the glycoside 166, the storage form of the pheromone. ${ }^{198}$ The equilibrium between 167 and the lactones favors the open form, but the increased volatility and lower polarity ensures vaporization and continued reformation of 157/158.

Niaviolides A and B (168 and 169) are produced as major components by the danaine butterfly Amauris niavius in their hairpencils, which are used to disseminate aphrodisiacs to the female during courtship. ${ }^{199}$ These compounds are very rare examples of sesquiterpene macrolides. The lactones have been synthesized by terminal oxidation of methyl farnesenoate and Sharpless epoxidation. ${ }^{199}$

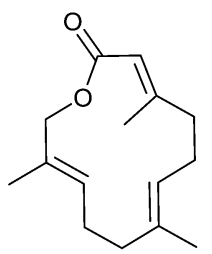

168

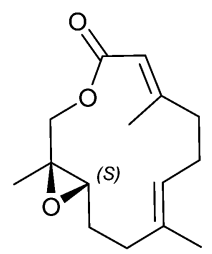

169
Gomadalactones A-C (170-172) are the major components of the most active fraction of the elytral secretion of females of the white-spotted longicorn beetle, Anoplophora malasiaca (Cerambycidae). ${ }^{\mathbf{2 0 0 , 2 0 1}}$ These bishomo-diterpenes serve as putative contact sex pheromones ensuring males contact a conspecific female. Hydrocarbons, typical contact sex pheromones of other cerambycids, and long chain ketones have synergistic effects. The absolute configuration has been established by analogy. ${ }^{202}$ A total synthesis of the gomadalactones has not been performed yet, although A. malasiaca is a serious pest of many trees such as willow, poplar, and citrus.
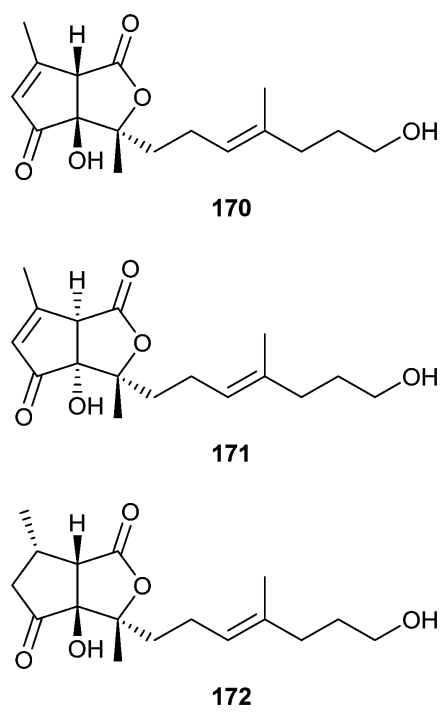

\section{Aromatic lactones}

Dihydroisocumarins are trail pheromones of different Camponotus ants (Hymenoptera: Formicinae), present in the rectal bladder, and the only aromatic semiochemicals discussed here. 3,4-Dihydro-8-hydroxy-3,7-dimethylisocoumarin (174) and 3,4dihydro-8-hydroxy-3,5,7-trimethylisocoumarin (175) act as trail pheromone components of C. silvicola, C. rufipes, C. balzani, and $C$. sericeiventris. ${ }^{203,204}$ Lactone 175 was also identified previously in Lasius niger. ${ }^{205}$ The biosynthesis in the ants follows a typical polyketide pathway incorporating malonate and methylmalonate to form a pentaketide precursor, as verified by feeding experiments. ${ }^{\mathbf{8 5}}$<smiles>C[C@@H]1Cc2cccc(O)c2C(=O)O1</smiles><smiles>Cc1ccc2c(c1O)C(=O)OC(C)C2</smiles><smiles>Cc1cc(C)c2c(c1O)C(=O)OC(C)C2</smiles>

The parent compound of the isocoumarins is mellein (173), a common fungal metabolite. It is present in the hindgut of the formicine ant Lasius fuliginosus. ${ }^{206}$ Trail following activity of workers is released by 173. Workers of this species are able to differentiate between the presence or absence of extra methyl groups in the aromatic ring system, because the structural 
analogs $\mathbf{1 7 4}$ and $\mathbf{1 7 5}$ failed to release trail following behavior in the bioassays. L. fuliginosus preferred to follow the trail of $(R)$ $(-)$-mellein as opposed to its $(S)-(+)$-enantiomer or the racemic mixture. Mellein has been reported from several ants ${ }^{207,208}$ and butterflies ${ }^{\mathbf{2 0 9 , 2 1 0}}$ without explicit functional description. It seems to have antibacterial activity against entomopathogenic bacteria. ${ }^{\mathbf{2 1 1}}$ Mellein has been often synthesized. Isocoumarin 174 is available by the gold catalyzed cyclisation of 2-furylethyl propargylates. ${ }^{212}$ The most highly methylated compound 175 has so far only been prepared with lithiation of benzoic acid amides as the key step. ${ }^{205}$

\section{Bacterial signals}

The most well described chemical communication system in bacteria is the so-called "quorum-sensing" system. Many bacteria secrete autoinducers that induce certain traits as the formation of biofilms, antibiotics, pigments, virulence factors and so on. By continuously emitting autoinducers, cells can sense the presence and abundance of related bacteria by the autoinducer concentration in their environment. If a certain threshold level of the autoinducer is reached physiological changes occur in a defined way. The bacteria sense by this method whether enough similar cells are present to have an impact on their immediate environment by coordinated action.

Many Gram-negative bacteria use $N$-acyl-L-homoserine lactones (AHLs) as autoinducers. The first autoinducer identified was $\mathrm{N}$-3-oxohexanoyl-L-homoserine lactone (3-oxo-C6-AHL, 176) from Vibrio fischeri which induces bioluminescence. ${ }^{213}$ Since then, many other AHLs, differing in the acyl side chain, have been identified in many different bacteria. A recent review covering the period until 2009 in this journal discuss the compounds and effects. ${ }^{3}$

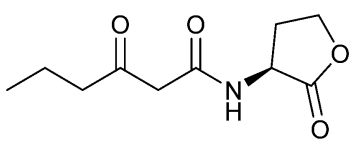

176

The structural modifications of known AHLs are shown in Fig. 22. The homoserinlactone ring is always $(S)$-/L-configured. The alkanoyl side chain has a length between $\mathrm{C}_{4}$ and $\mathrm{C}_{18}$ and can carry an alcohol or keto group at C-3, or an $(E)$-configured double bond at C-2. The alkyl chain is usually unbranched, with the exception of a few known iso-compounds, and is saturated or may carry a double bond at the $\omega$-7-positon in compounds with $\mathrm{C}_{12}$ or longer alkanoyl chains. Probably an exception is $\mathrm{N}$ dodecenoyl-HSL from Rhodobacter sphaeroides, for which a C-7 double bond was proposed based on MS data alone, but not verified by other methods, ${ }^{214}$ as well as 187 (see below) with a $\omega$ 6 double bond. Bacteria secrete AHLs either as single compounds or in mixtures of several components. These mixtures are believed to be species or even strain specific, allowing species recognition and a differentiated response depending on the AHL variety detected. For example, 24 different AHLs have been reported from Yersinia pseudotuberculosis. $^{215}$ Although there is species specific variety in the AHL structures produced and in the respective receptors, the overall structural variability observed so far is much lower as, for example, in female lepidopteran sex pheromones. In the latter, besides variation in the terminal functional group and chain length, variability is also found in the numbers, location and configuration of double bonds in the chain, a feature not found in AHLs. ${ }^{216}$ Another type of acyl side chain occurs in the coumaric acid derivative $177,{ }^{217}$ which is formed in Rhodopseudomonas palustris, Bradyrhizobium sp. and Silicibacter pomeroyi by using environmentally supplied coumaric acid instead of the fatty acid pool in the cell.

In many bacteria the quorum-sensing system is homologous or related to the system present in $V$. fischeri. ${ }^{218} V$. fischeri is a symbiotic bacterium found in the light organ of the Hawaiian bobtailed squid Euprymna scolopes and the Japanese pinecone fish Monocentris japonica. The standard quorum sensing system consists of a combination of $l u x I$ and $l u x R$ genes that can promote other lux genes. The expression of these genes depends on the cell density and the concentration of 177 , which is synthesized by LuxI and released into the environment. The HSL (homoserine lactone) binds to LuxR and this complex activates an operon including luxI and other genes responsible for bioluminescence (Fig. 23). By this feedback loop more 177 is produced. ${ }^{219,220}$ Another quorum sensing circuit using C8-AHL is also expressed in $V$. fischeri, as is the autoinducer AI-2 system, using a pentose-borate ester as a signal. ${ }^{218,221}$

The chemical behaviour of AHLs has recently been discussed in detail. ${ }^{222}$ Due to their $\alpha$-amido group, HSLs are less stable than other lactones. Under basic conditions irreversible lactone ring cleavage occurs, ${ }^{223}$ although degradation, e.g. in sea water, ${ }^{224}$ is much slower than expected.

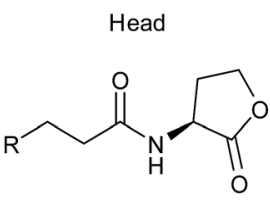<smiles>[R]C=CC(=O)N[C@H]1CCOC1=O</smiles><smiles>[R]C(O)CC(=O)N[C@H]1CCOC1=O</smiles><smiles>[R]C(=O)CC(=O)N[C@H]1CCOC1=O</smiles>

Tail

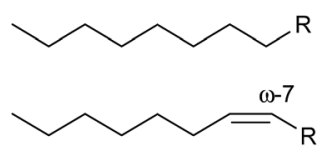<smiles>[R]CCCCCCC(C)C</smiles><smiles>O=C(/C=C/c1ccc(O)cc1)N[C@@H]1CCOC1=O</smiles>

Fig. 22 Structural features found in $N$-acylhomoserine lactones. The acyl side chain can carry a saturated, $\alpha, \beta$-conjugated unsaturated, $(R)$ $\beta$-hydroxycarbonyl, or $\beta$-dicarbonyl head group. The absolute configuration is (S)/L. The tail is either saturated or unsaturated at the $\omega-7$ position. In rare cases an iso-chain is found. The alkanoyl chain length varies between $\mathrm{C}_{4}$ and $\mathrm{C}_{18}$. Odd numbered chains are rarely observed. Aromatic HSLs such as 177 have been identified in a few cases only. 

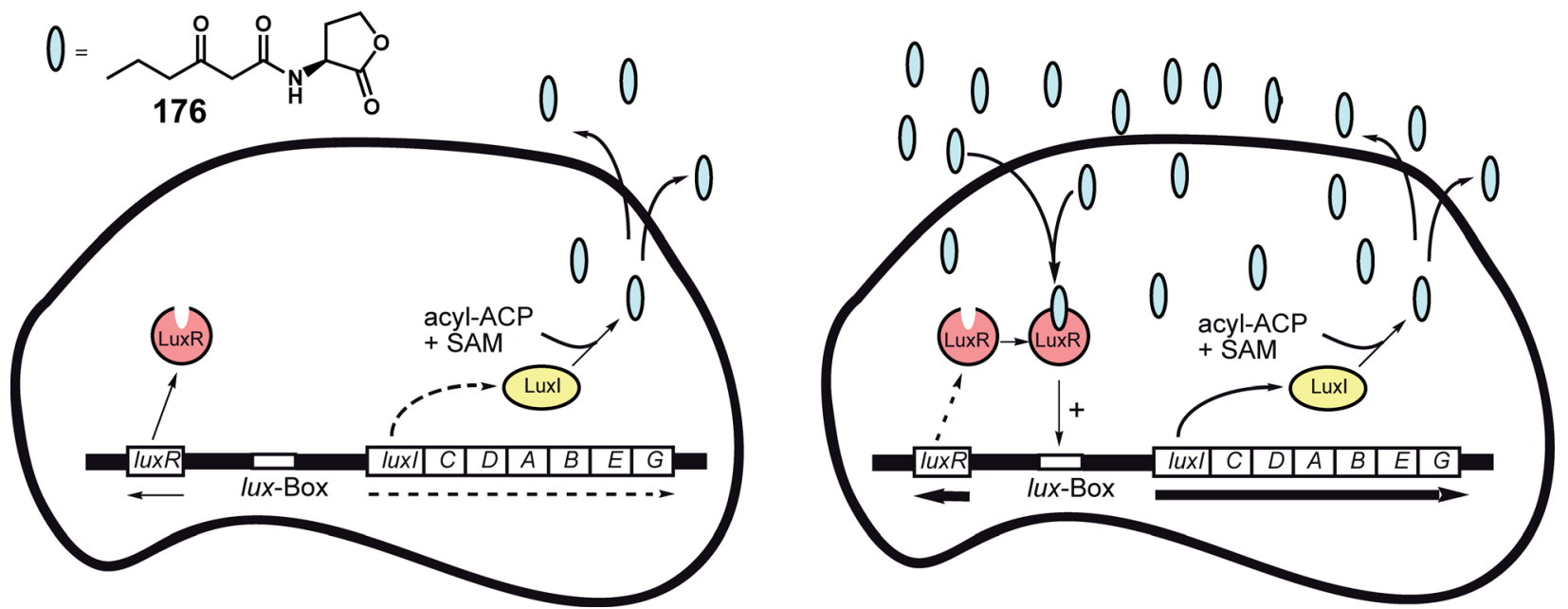

Fig. 23 The Vibrio fischeri quorum-sensing system. At low cell densities (left) luxl and luxR are expressed in low levels. AHL 176 synthesized by the AHL synthase Luxl from 3-oxohexanoly-ACP (acyl carrier protein) and SAM (S-adenosylmethionine) diffuses out of the cell. At high cell densities (right) AHLs bind and activate the LuxR transcriptional activator. LuxR binds to a so called lux box. This stimulates the expression of the luxICDABE genes. The expression of the luxR gene is regulated by several factors. At high concentrations LuxR can repress itself. ${ }^{220}$

Homoserine lactones are synthesized by LuxI-type synthases from an acyl-carrier protein bound acyl precursor 178 and $S$ adenosylmethionine (179) as shown in Fig. 24. The details have

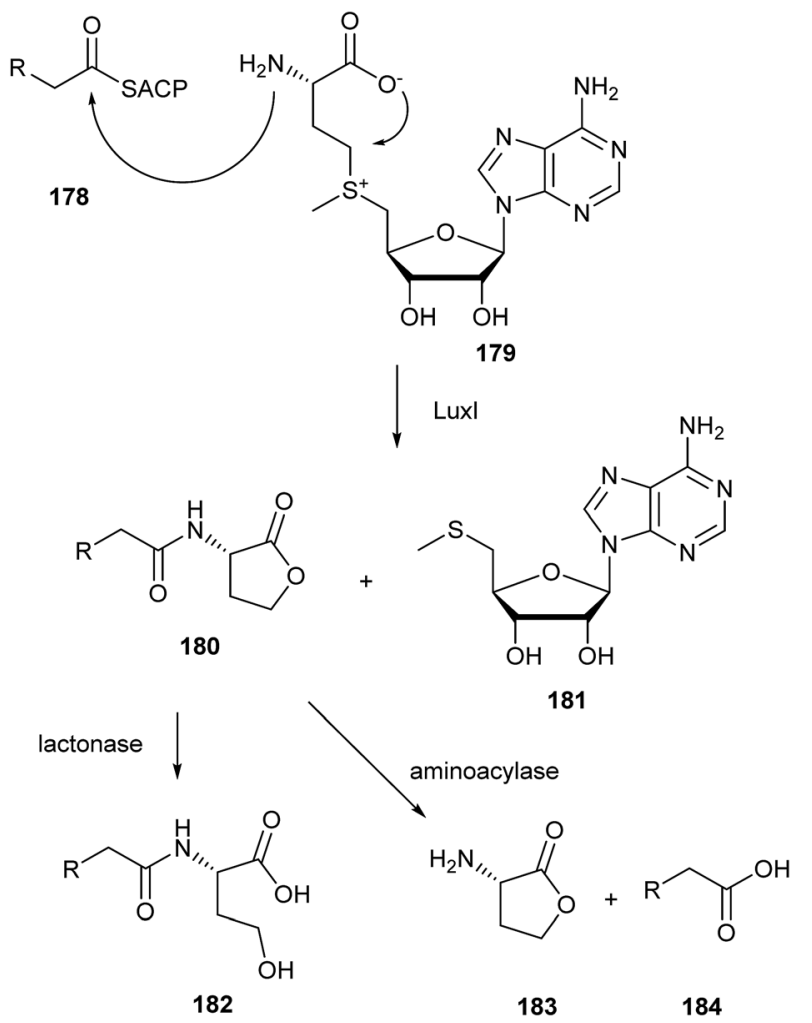

Fig. 24 Biosynthesis of $N$-acylhomoserine lactones (180) by Luxl from S-adenosylmethionine (179) and an acyl carrier protein bound acyl precursor. Enzymatic degradation of 180 occurs by bacterial enzymes as $\mathrm{AHL}$ lactonases, that cleave the lactone 180 or $\mathrm{AHL}$ aminoacylases that cleave the amide bond to give 183 and 184 . been reviewed. ${ }^{225}$ An acyl carrier protein bound fatty acid is transferred to the amino group whereas the lactone ring is closed to release methylthioadenosine (181). Several bacteria can secrete enzymes that can degrade AHLs, either by a lactonase or an aminoacylase (Fig. 24). These degrading enzymes are important to modulate the signal in the environment. They can turn off quorum-sensing systems, and their action is therefore called quorum quenching. ${ }^{3}$

Until 2009, about 50 different AHLs have been described, although the positions and configurations of the double bonds in unsaturated AHLs were verified only in a few cases. ${ }^{3}$ Since then, some new AHLS have been discovered.

Isovaleryl-HSL (185) is produced by the soybean symbiont Bradyrhizobium japonicum and is active in the picomolar range, compared to nanomolar range activity of HSL in other bacteria. ${ }^{226}$ The function for the bacterium is still unknown. The producing enzyme BjaI, a LuxI homolog, shows some similarity to the enzymes RpaI, from Rhodopseudomonas palustris producing aromatic $177^{217}$, and BtaI from a root-nodulating Bradyrhizobium strain ${ }^{227}$ respectively. The latter forms cinnamoyl-HSL (186) from endogenous cinnamic acid. All these enzymes seem to use a CoA-bound alkanoyl substrate, in contrast to the usual ACP-alkanoyl substrate typical for LuxI homologues. ${ }^{226}$ The first fully characterized unsaturated AHL violating the $\omega$-7 rule is $(Z)-4$-decenoyl-HSL (187). It has been isolated from the fungus Mortierella alpina that contained the $\beta$ proteobacterium Castellaniella defragrans and Gram positive Cryobacterium sp. as endobacteria, in addition to C7- and C8HSL. ${ }^{228,229}$ The role of these AHLS in the symbiosis between fungus and bacteria is unknown. The roseobacter bacterium Dinoroseobacter shibae produces $(2 E, 11 Z)-N$-octadeca-2,11dienoyl-HSL (188) as the major metabolite of one of its luxI homologues. The complete characterization was only possible after overexpression of $l u x I_{1}$ in $D$. shibae itself because the wild 

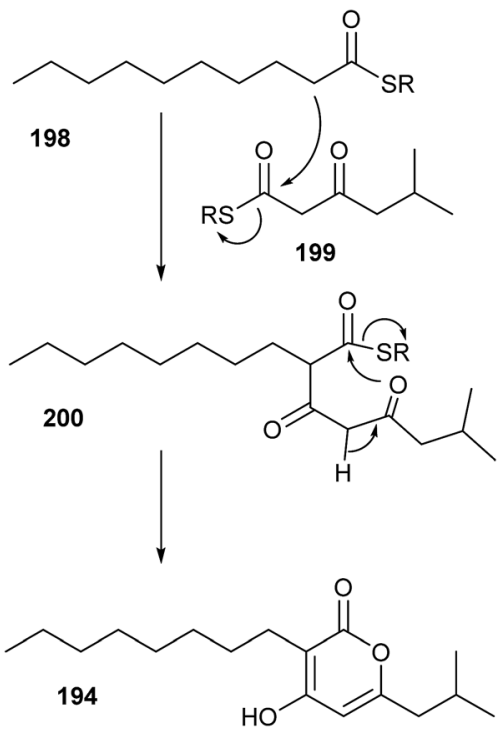

Fig. 25 Proposed biosynthesis of photopyrones of Photorhabdus $\mathrm{sp}^{237} \mathrm{R}=$ an activating group like CoA or another thioester.

type produced only low amounts. Overexpression in E. coli was not helpful because this construct did not produce 188 anymore, but shorter AHLs such as 3-OH-C14-AHL. ${ }^{230}$ Only two other dienoyl-HSLs are known, 2E,9Z-C16:2-HSL from another roseobacter, Jannaschia helgolandensis, ${ }^{231}$ and an incompletely characterized AHL from Methylobacterium extorquens, likely 2E,7Z-C14:2-HSL. ${ }^{232}$ The HSL 188 and its co-occurring hydrogenated analogue Z11-C18:1-HSL regulate cell-division, flagellae formation and the type IV secretion system T4SS, established by experiments with mutants and substitution with synthetic

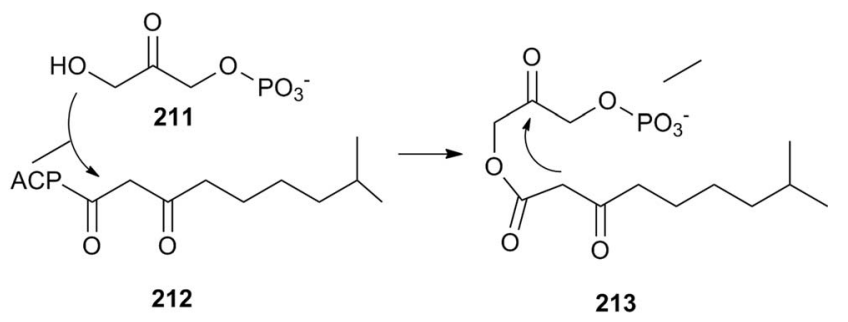<smiles>CCCCCC(=O)C1=C(CO)COC1=O</smiles>

201

Fig. 26 Biosynthesis of the A factor. The terminal $\mathrm{OH}$ group might be phosphorylated during these transformations.

AHLs. ${ }^{233}$ In this system the quorum-sensing system obviously induces phenotypic individualization rather than population coordination. In changing environments, e.g. algal blooms in which these bacteria can occur, the differentiation might be beneficial because of the highly fluctuating environmental restraints. ${ }^{233}$

The ecological role of quorum sensing in complex communities has been investigated by a long-term bioreactor study. The conversion of coagulating biomass to granules was found to be strongly positively correlated with AHL-mediated quorum sensing. Specific AHLs such as C4-HSL, C8-HSL or 3-oxo-C8-HSL were up to 100 -fold increased when granulation started. During granular disintegration the AHL concentration decreased. AHL addition led to increased exopolysaccharide formation. AHLs were active in the picomolar to nanomolar range. The authors state that "AHL mediated quorum sensing may be a common feature in many natural and engineered ecosystems, where it coordinates community behaviour." ${ }^{234}$<smiles>CC(C)CCC(=O)NC1CCOC1=O</smiles>

185<smiles>CCCCC/C=C/CCC(=O)NC1CCOC1=O</smiles>

187<smiles>CCCCCC/C=C/CCCCCCC/C=C/C(=O)N[C@H]1CCOC1=O</smiles>

Usually LuxR homologues are regulators activated by HSL and occur as luxI luxR pairs in the bacterial genome. In some cases so called orphan $l u x R$ genes are found, probably activated by compounds other than AHLs. ${ }^{235,236}$ The insect pathogenic proteobacterium Photorhabdus luminescens expresses the solo receptor PluR, but no AHLs. PluR detects an endogenous signal, the photopyrones 189-196, and regulates secretory proteins responsible for cell clumping. The different compounds were differently active and occurred in strain specific mixtures. ${ }^{237}$ While photopyrone D (190) showed the highest activity even in the very low concentration of $3.5 \mathrm{pmol}$ in P. luminescens, photopyrones A (193) and B (189) dominate in $P$. temperata. Closely related lactones, pseudopyronines such as 197, have been isolated from Pseudomonas sp., ${ }^{238,239}$ indicating that these signalling compounds are more widespread in the bacterial kingdom. The biosynthesis of photopyrones likely includes a head-to-head fusion of two activated short-chain fatty acids 198 and 199 mediated by Ppys as shown in Fig. 25. The intermediate 200 is then lactonized to 194. This mechanism is supported by the expression of respective genes in E. coli. ${ }^{237}$ Similar to the AHLs, the long alkyl side chain might help to enter the target cell and in reaching the receptor. ${ }^{240}$ 


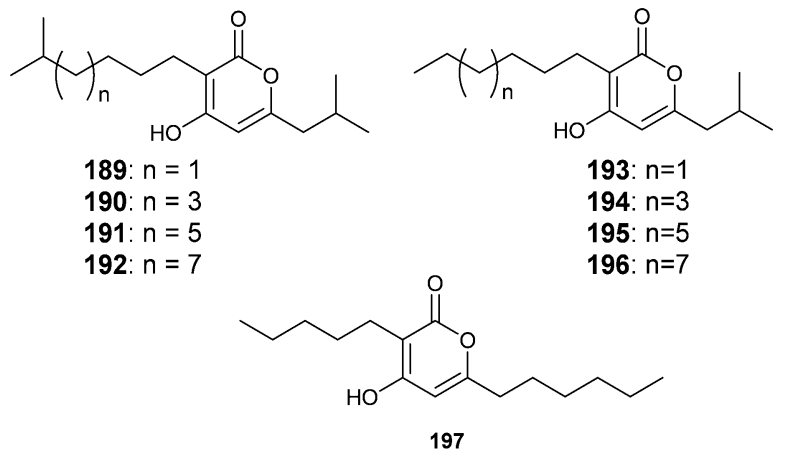

Streptomycetes use the A-factor family of butanolides to regulate their production of secondary metabolites. ${ }^{241-243}$ The Afactor (201) itself was identified by Khokhlov. The originally proposed stereochemistry ${ }^{\mathbf{2 4}}$ was revised by Mori's synthesis. ${ }^{245,246}$ The A-factor induced simultaneous sporulation and streptomycin biosynthesis in Streptomyces griseus, ${ }^{247}$ and is active in concentrations as low as $10^{-9} \mathrm{~mol} \mathrm{l}^{-1}$. This autoregulator was the first of a family of related butanolides, used by

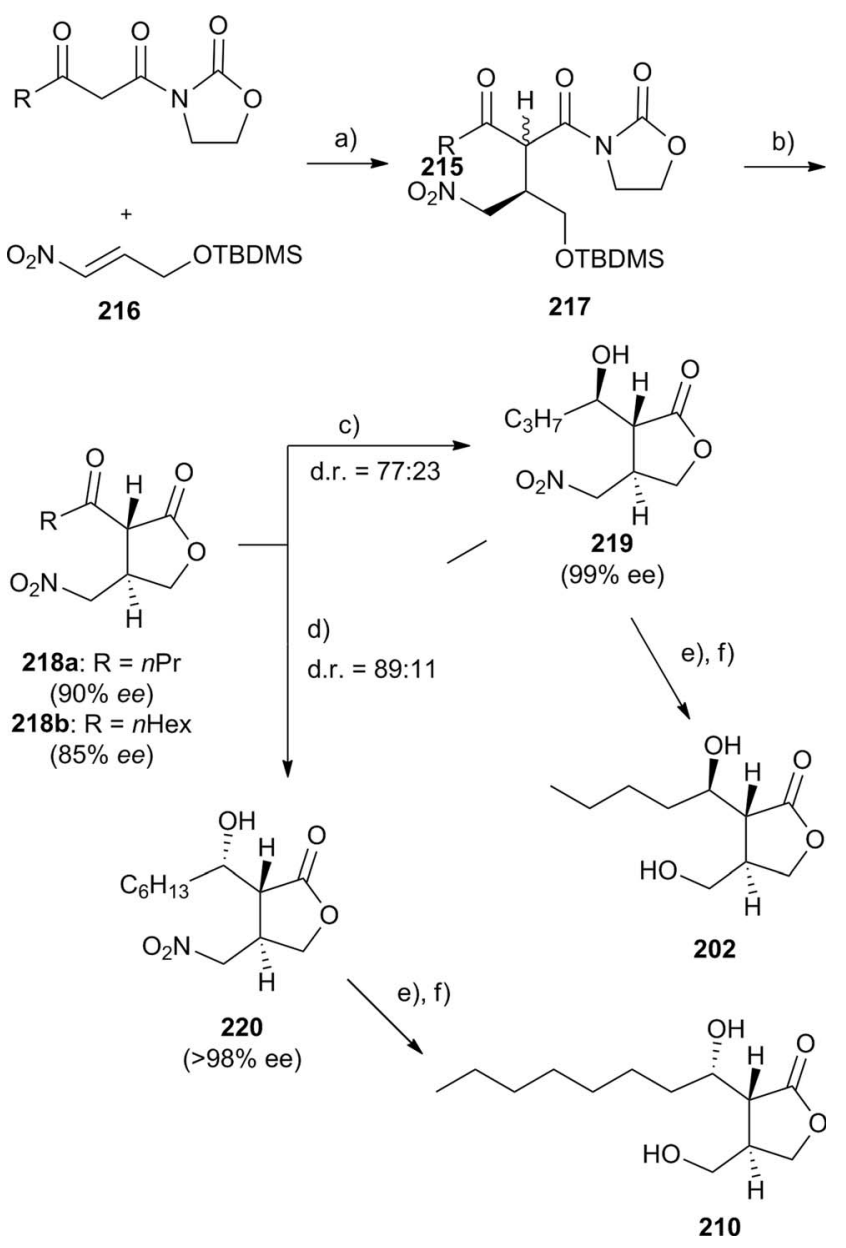

Fig. 27 Modular synthesis of butyrolactone autoinducers. ${ }^{262}$ (a) ureamodifed chinchona alkaloid catalyst, toluene; (b) $\mathrm{HCl}, \mathrm{H}_{2} \mathrm{O}$, EtOAc; (c) $(\mathrm{S}, \mathrm{S})$-Nojori $\mathrm{Ru}$ transfer hydrogenation catalyst, $\mathrm{CH}_{2} \mathrm{Cl}_{2}$; (d) $(R, R)$ Nojori Ru transfer hydrogenation catalyst, $\mathrm{CH}_{2} \mathrm{Cl}_{2}$; (e) $\mathrm{NaNO}_{2}, \mathrm{AcOH}$, DMF; (f) $\mathrm{BH}_{3} \cdot \mathrm{SMe}_{2}$, THF. other streptomycetes, often in species specific mixtures. The virginiae butanolides (206-210) control virginiamycin production in $S$. virginiae, ${ }^{248}$ whereas IM-2 (202) evokes the production of antibiotics in $S$. lavendulae. ${ }^{249}$ The SCBs 1 to 3 (203-205) regulate the formation of antibiotics in $S$. coelicolor. ${ }^{250}$ Several other effects have been described, but antibiotic production and spore formation are not triggered in all cases by these signals. ${ }^{\text {243,251 }}$ Butanolide receptor genes have also been identified outside Streptomyces, e.g. in Kitasatospora, ${ }^{252}$ indicating a broader communicative role of these compounds. ${ }^{253}$ A related butanolide structure was postulated for the diffusible signal factor, a quorum-sensing signal, of Gram negative Xanthomonas campestris, based on mass spectral data. ${ }^{254}$ Subsequent synthesis and further experiments showed the compound to be 3-hydroxybenzoic acid. ${ }^{255,256}$

The biosynthesis of the A-factor, which is released in very small amounts, starts with dihydroxyacetone phosphate (211) and 8-methyl-3-oxononanoyl-ACP (211), leaked from fatty acid synthases. The A-factor biosynthesis enzyme, AfsA, induces ester formation to $\mathbf{2 1 3}$, followed by an aldol type ring closure process to form 214. Finally, a stereospecific reductase furnishes the A-factor. A non-specific phosphatase is also involved in this process (Fig. 26). ${ }^{257}$<smiles>CC(C)CCCCC(=O)C1C(=O)OC[C@H]1CO</smiles><smiles>[R]C(O)[C@H]1C(=O)OC[C@@H]1CO</smiles>

Butenolides have been synthesized by various methods, including lipase catalysed resolution. ${ }^{258-261}$ The Jorgenson group addressed the stereochemistry of these autoregulators by a recent modular synthesis (Fig. 27). ${ }^{262}$ A $\beta$-keto acid already containing the required alkyl chain of the butanolides is transformed into the oxazoline amide 215. These amides add, by catalysis of urea-modified cinchona alkaloids, good stereoselectivity to the nitroalkene 216. Upon treatment with acid, lactones $\mathbf{2 1 8}$ are formed in good to high enantioselectivity. Enantioselective hydrogenation using a Noyori ruthenium transfer hydrogenation catalyst can form either the $R$ - or $S$ configured side chains, depending on the catalyst ligands used. Finally, transformation of the nitro group into an alcohol forms 
the required autoregulators in a short synthesis and in high enantiomeric purity.

The lactone motif occurs also in peptides used as quorumsensing autoinducers by Gram-positive bacteria of the Staphylococcus group. These autoinducing peptides contain between 7 and 9 amino acids and usually a thiolactone or simple lactone ring.

Because the lactone motif is only one structural feature apart from many others, we will not go into a detailed discussion of these peptides. Common to many other cyclic peptides, the cyclic nature may prevent degradation by ubiquitous proteases. Examples of such peptides are the Staphylococcus aureus autoinducing peptide AIP-IV (222), ${ }^{\mathbf{2 4 3}}$ Lactobacillus plantarum LAMD558 (223), ${ }^{263}$ and Enterococcus faecalis gelatinase biosynthesis-activating pheromone (223), leading to expression of a virulence factor. ${ }^{264-266}$

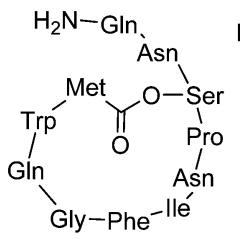

221

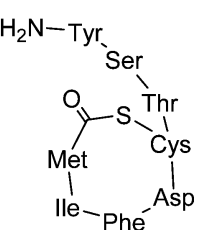

222

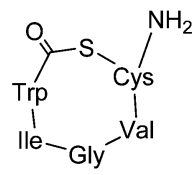

223

\section{Discussion}

This review discussed semiochemical lactones and showed that they are synthesised by organisms along some preferred biosynthetic pathways. Arthropod and animal lactones are often derived from fatty acids. A general picture of fatty acid derived lactone formation is shown in Fig. 28. Common fatty acids serve as starting materials and are modified by chain-shortening and oxidation processes. The latter are either generated by oxidation of non-activated carbon atoms near the end of the chain (most likely produced by cytochrom P450 dependent oxidases), oxidation of double bonds with concomitant double bond migration (typical products of lipoxygenases), or finally by epoxidation followed by ring opening, mediated by monooxygenases. These processes lead to storable hydroxy acid precursors which can be cyclized to lactones when needed. Similar oxidation processes and cyclization pathways can be found among the terpenes discussed, where often terminal oxidation leads to precursors of the lactones, hydroxy acids or related storage forms.

Nevertheless, no hydroxyacid precursor is necessary in other cases, e.g. in polyketide derived lactones such as $\mathbf{9 , 4 3}$, or 174 . Although no detailed genomic studies on their biosynthesis have been performed, investigations on macrolide polyketide antibiotics suggest that direct lactone formation takes place by the final thioesterase removing the growing chain from the polyketide synthase without formation of the hydroxyacid.
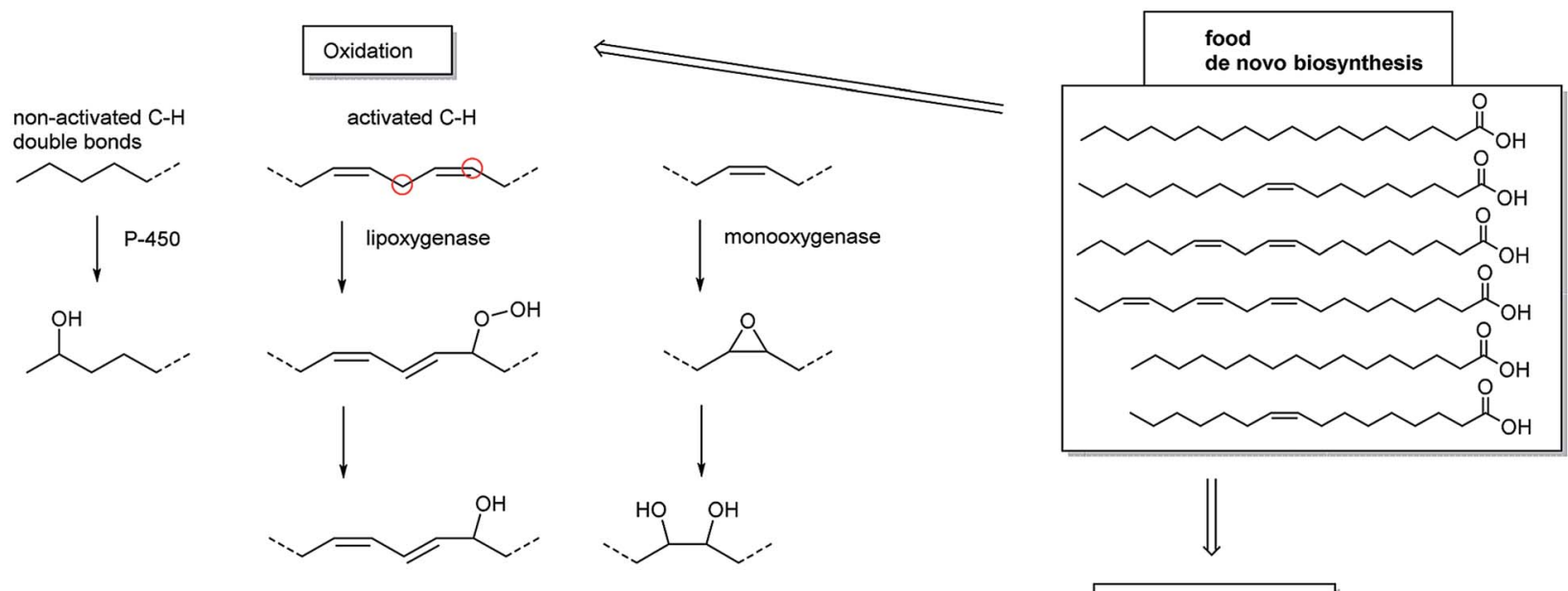

Chain-shortening
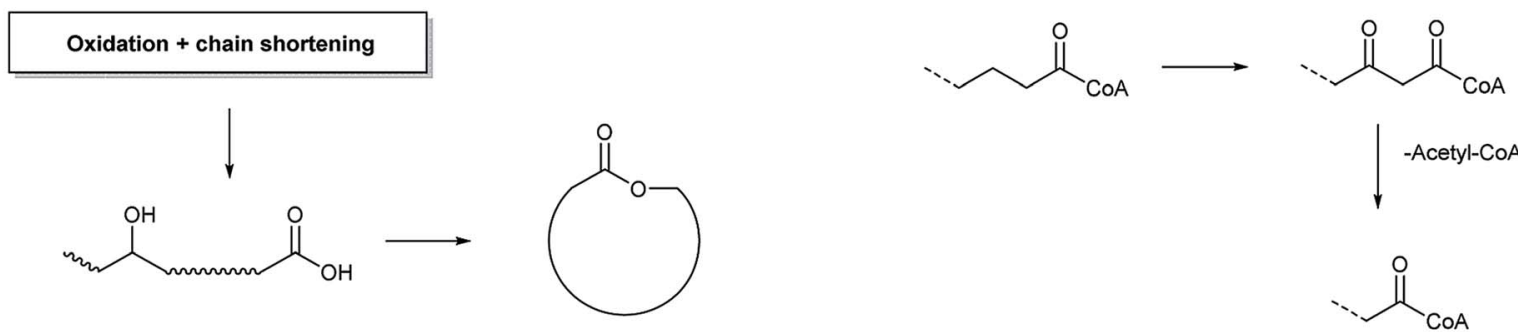

Fig. 28 Biosynthesis of lactone formation of the fatty acid pool. Fatty acids are used as a starting point for lactone formation using general strategies such as chain-shortening or defined oxidation. Finally, the hydroxyacid precursor can be cyclised to the more volatile lactone. 
Nevertheless, an alternative process via a hydroxyacid cannot be ruled out.

In contrast, bacterial signalling lactones do not need to have a storage form and, therefore, no hydroxy acid precursor is involved in the biosynthesis of the known examples. The lactone is directly formed by substitution or condensation reactions. Variation lies mostly in the chain length of the lipohilic side chain, present in all lactones discussed, but not so much in the core lactone unit. Nevertheless, because of the still limited number of bacterial signalling compounds, this point has to be looked upon with caution.

\section{Conclusion}

The lactone motif is an important structural feature of small molecule signalling compounds found in different organisms such as insects, vertebrates, plants, or microorganisms. Stereochemistry seems to play an essential role in ensuring specificity in many of the discussed systems. ${ }^{267}$ Synthetic routes to many, but not all, of these lactones exist, addressing the important stereochemical issues. While the biosynthetic routes to bacterial signalling compounds are well established using genetic and enzymatic methods, this is the case only in a few cases for higher organisms such as insects or vertebrates.

\section{Acknowledgements}

We thank our colleagues M. Ayasse, Ulm, J. Ruther, Regensburg, K. Mori, Tokyo, and W. Francke, Hamburg, for helpful comments on the manuscript.

\section{References}

$1 \mathrm{~W}$. Francke and S. Schulz, in Comprehensive Natural Products Chemistry, ed. D. Barton, K. Nakanishi, O. MethCohn and K. Mori, Elsevier, Amsterdam, 1999, vol. 8, pp. 197-261.

$2 \mathrm{~W}$. Francke and S. Schulz, in Comprehensive Natural Products II, ed. L. N. Mander and H.-W. Liu, Elsevier, Oxford, 2010, vol. 4, pp. 153-223, ed. K. Mori.

3 J. S. Dickschat, Nat. Prod. Rep., 2010, 27, 343-369.

4 R. G. Yarger, R. M. Silverstein and W. E. Burkholder, J. Chem. Ecol., 1975, 1, 323-334.

5 R. E. Greenblatt, W. E. Burkholder, J. C. Cross, R. C. Byler and R. M. Silverstein, J. Chem. Ecol., 1976, 2, 285-297.

6 K. N. Slessor, L.-A. Kaminski, G. G. S. King, J. H. Borden and M. L. Winston, Nature, 1988, 332, 354-356.

7 B. D. Morris, R. R. Smyth, S. P. Foster, M. P. Hoffmann, W. L. Roelofs, S. Franke and W. Francke, J. Nat. Prod., 2005, 68, 26-30.

8 R. R. Smyth and M. P. Hoffmann, J. Insect Behav., 2003, 16, 347-359.

9 Y. Schmidt and B. Breit, Org. Lett., 2009, 11, 4767-4769.

10 Y. Schmidt, K. Lehr, U. Breuninger, G. Brand, T. Reiss and B. Breit, J. Org. Chem., 2010, 75, 4424-4433.

11 C. F. Weise, M. Pischl, A. Pfaltz and C. Schneider, Chem. Commun., 2011, 47, 3248-3250.
12 C. F. Weise, M. C. Pischl, A. Pfaltz and C. Schneider, J. Org. Chem., 2012, 77, 1477-1488.

13 J. S. Yadav, E. Srinivas, C. K. Sureshkumar, A. A. K. Al Ghamdi and E. A. Baqshan, Synthesis, 2012, 628-634.

14 R. Nishida, S. Schulz, C. H. Kim, H. Fukami, Y. Kuwahara, K. Honda and N. Hayashi, J. Chem. Ecol., 1996, 22, 949-972.

15 S. Schulz and R. Nishida, Bioorg. Med. Chem., 1996, 4, 341-349.

16 K. Stritzke, S. Schulz and R. Nishida, Eur. J. Org. Chem., 2002, 3884-3892.

17 Y. Honda, K. Honda and H. Omura, J. Insect Physiol., 2006, 52, 1043-1053.

18 S. Schulz, G. Beccaloni, K. S. Brown Jr, M. Boppré, A. V. L. Freitas, P. Ockenfels and J. R. Trigo, Biochem. Syst. Ecol., 2004, 32, 699-713.

19 T. Eisner and J. Meinwald, Proc. Natl. Acad. Sci. U. S. A., 1995, 92, 50-55.

20 S. Weber, W. Eisenreich, A. Bacher and T. Hartmann, Phytochemistry, 1999, 50, 1005-1014.

21 J. A. Edgar, C. C. J. Culvenor and T. E. Pliske, J. Chem. Ecol., 1976, 2, 263-270.

22 W. A. Haber, Evolutionary ecology of tropical mimetic butterflies (Lepidoptera: Ithomiinae), Ann Arbor, 1978.

23 J. Knudsen, R. Eriksson, J. Gershenzon and B. Ståhl, Bot. Rev., 2006, 72, 1-120.

24 S. Schulz and J. S. Dickschat, Nat. Prod.Rep., 2007, 24, 814842 .

25 K. Honda, H. Omura, M. Hori and Y. Kainoh, in Comprehensive Natural Products II, ed. L. N. Mander and H.-W. Liu, Elsevier, Oxford, 2010, vol. 4, pp. 563-594, ed. K. Mori.

26 J. Li, Z. Wang, Y. Qu, K. Tan and J. C. Nieh, J. Exp. Biol., 2014, 217, 3512-3518.

27 W. S. Leal, Naturwissenschaften, 1991, 78, 521-523.

$28 \mathrm{~W}$. S. Leal, M. Sawada and M. Hasegawa, Naturwissenschaften, 1993, 80, 181-183.

29 W. S. Leal, F. Kawamura and M. Ono, J. Chem. Ecol., 1994, 20, 1667-1676.

30 W. S. Leal, M. Hasegawa, M. Sawada, M. Ono and Y. Ueda, J. Chem. Ecol., 1994, 20, 1643-1655.

31 M. Toth, M. Subchev, I. Sredkov, I. Szarukan and W. Leal, J. Chem. Ecol., 2003, 29, 1643-1649.

32 W. S. Leal, P. H. G. Zarbin, H. Wojtasek and J. T. Ferreira, Eur. J. Biochem., 1999, 259, 175-180.

33 C. Romero-Guido, I. Belo, T. Ta, L. Cao-Hoang, M. Alchihab, N. Gomes, P. Thonart, J. Teixeira, J. Destain and Y. Waché, Appl. Microbiol. Biotechnol., 2011, 89, 535-547.

34 J. S. Dickschat, I. Wagner-Döbler and S. Schulz, J. Chem. Ecol., 2005, 31, 925-947.

35 J. H. Tumlinson, M. G. Klein, R. E. Doolittle, T. L. Ladd and A. T. Proveaux, Science, 1977, 197, 789-792.

36 Y. Ishida and W. S. Leal, Proc. Natl. Acad. Sci. U. S. A., 2008, 105, 9076-9080.

37 L. Lin, Q. Zhao, A. N. Li, F. Ren, F. Yang and R. Wang, Org. Biomol. Chem., 2009, 7, 3663-3665.

38 S. M. Totokotsopoulos, E. E. Anagnostaki, C. I. Stathakis, E. G. Yioti, C. Z. Hadjimichael and J. K. Gallos, ARKIVOC, 2009, 10, 209-219. 
39 M. C. Larsson, J. Hedin, G. P. Svensson, T. Tolasch and W. Francke, J. Chem. Ecol., 2003, 29, 575-587.

40 M. Kakizaki, H. Sugie, K. Honma, T. Fukumoto, K. Kawasaki, H. Noguchi, M. Ohtaishi and H. Suzuki, Appl. Entomol. Zool., 1998, 33, 5-10.

41 W. S. Leal, S. Kuwahara, M. Ono and S. Kubota, Bioorg. Med. Chem., 1996, 4, 315-321.

42 T. Nakayama and K. Mori, Liebigs Ann./Recl., 1997, 1997, 839-843.

43 A. A. Cosse, R. J. Bartelt, D. G. James and R. J. Petroski, J. Chem. Ecol., 2001, 27, 1841-1853.

44 C. Shibata and K. Mori, Eur. J. Org. Chem., 2004, 1083-1088. 45 K. Mori, Eur. J. Org. Chem., 2005, 2040-2044.

46 G. Sabitha, K. Yadagiri and J. S. Yadav, Tetrahedron Lett., 2007, 48, 1651-1652.

47 A. Habel and W. Boland, Org. Biomol. Chem., 2008, 6, 16011604.

48 B. V. Burger, M. Z. Viviers, J. P. I. Bekker, M. Roux, N. Fish, W. B. Fourie and G. Weibchen, J. Chem. Ecol., 2008, 34, 659671.

49 D. Müller-Schwarze, U. Ravid, A. Claesson, A. G. Singer, R. M. Silverstein, C. Müller-Schwarze, N. J. Volkman, K. F. Zemanek and R. G. Butler, J. Chem. Ecol., 1978, 4, 247-256.

50 B. V. Burger, A. E. Nell, H. S. C. Spies, M. Le Roux and R. C. Bigalke, J. Chem. Ecol., 1999, 25, 2085-2097.

51 B. V. Burger, in The chemistry of pheromones and other semiochemicas, Vol. II, ed. S. Schulz, Springer, Berlin, 2005, pp. 231-278.

52 Y.-S. Jo, J.-U. An and D.-K. Oh, J. Agric. Food Chem., 2014, 62, 6736-6745.

53 T. Ikan, R. Gottlieb, E. D. Bergmann and J. Ishay, J. Insect Physiol., 1969, 15, 1709.

54 A. Harbindu, B. M. Sharma and P. Kumar, Tetrahedron: Asymmetry, 2013, 24, 305-314.

55 T. Fischer and J. Pietruszka, Adv. Synth. Catal., 2012, 354, 2521-2530.

56 J. Ruther, L. M. Stahl, S. Steiner, L. A. Garbe and T. Tolasch, J. Exp. Biol., 2007, 210, 2163-2169.

57 S. Steiner and J. Ruther, J. Chem. Ecol., 2009, 35, 416-421.

58 J. Ruther, M. Matschke, L.-A. Garbe and S. Steiner, Proc. $R$. Soc. B, 2009, 276, 3303-3310.

59 J. Ruther, in Chemical Ecology of Insect Parasitoids, John Wiley and Sons, 2013, pp. 112-144.

60 B. Blaul, R. Steinbauer, P. Merkl, R. Merkl, H. Tschochner and J. Ruther, Insect Biochem. Mol. Biol., 2014, 51, 33-40.

61 M. Abdel-Latief, L. A. Garbe, M. Koch and J. Ruther, Proc. Natl. Acad. Sci. U. S. A., 2008, 105, 8914-8919.

62 O. Niehuis, J. Buellesbach, J. D. Gibson, D. Pothmann, C. Hanner, N. S. Mutti, A. K. Judson, J. Gadau, J. Ruther and T. Schmitt, Nature, 2013, 494, 345-348.

63 C. P. Burke and Y. Shi, Org. Lett., 2009, 11, 5150-5153.

64 A. Yajima, Tetrahedron Lett., 2014, 55, 2773-2780.

65 S. Schulz, Chem. Commun., 1999, 1239-1240.

66 G. Sabitha, N. Fatima, E. Venkata Reddy and J. S. Yadav, Tetrahedron Lett., 2008, 49, 6087-6089.
67 H. J. Williams, M. Wong, R. Wharton and S. B. Vinson, J. Chem. Ecol., 1988, 14, 1727-1736.

68 G. C. Paddon-Jones, C. J. Moore, D. J. Brecknell, W. A. König and W. Kitching, Tetrahedron Lett., 1997, 38, 3479-3482.

69 D. A. Chaudhari, P. Kattanguru and R. A. Fernandes, Tetrahedron: Asymmetry, 2014, 25, 1022-1025.

70 A. M. Lone, B. A. Bhat, W. A. Shah and G. Mehta, Tetrahedron Lett., 2014, 55, 3610-3612.

71 B. R. Laurence and J. A. Pickett, J. Chem. Soc., Chem. Commun., 1982, 59-60.

72 B. R. Laurence, K. Mori, T. Otsuka, J. A. Pickett and L. J. Wadhams, J. Chem. Ecol., 1985, 11, 643-648.

73 Y. Mao, X. Xu, W. Xu, Y. Ishida, W. S. Leal, J. B. Ames and J. Clardy, Proc. Natl. Acad. Sci. U. S. A., 2010, 107, 1910219107.

74 B. Sun, L. Peng, X. Chen, Y. Li, Y. Li and K. Yamasaki, Tetrahedron: Asymmetry, 2005, 16, 1305-1307.

75 H.-B. Dong, M.-Y. Yang, X.-T. Zhang and M.-A. Wang, Tetrahedron: Asymmetry, 2014, 25, 610-616.

76 S. Das, A. K. Mishra, A. Kumar, A. A. K. Al Ghamdi and J. S. Yadav, Carbohydr. Res., 2012, 358, 7-11.

77 S. Singh and P. J. Guiry, Eur. J. Org. Chem., 2009, 1896-1901. 78 J. R. Rocca, J. H. Tumlinson, B. M. Glancey and C. S. Lofgren, Tetrahedron Lett., 1983, 24, 1889-1892.

79 E. Janssen, B. Hölldobler, F. Kern, H. J. Bestmann and K. Tsuji, J. Chem. Ecol., 1997, 23, 1025-1034.

80 S. M. Wickel, C. A. Citron and J. S. Dickschat, Eur. J. Org. Chem., 2013, 2906-2913.

81 H. J. Bestmann, U. Haak, F. Kern and B. Hoelldobler, Naturwissenschaften, 1995, 82, 142-144.

82 H. J. Bestmann, B. Liepold, A. Kress and A. Hofmann, Chem.-Eur. J., 1999, 5, 2984-2989.

83 E. Kohl, B. Hölldobler and H. J. Bestmann, Chemoecology, 2001, 11, 67-73.

84 W. Pinyarat and K. Mori, Biosci., Biotechnol., Biochem., 1993, 57, 419-421.

85 H. J. Bestmann, E. Übler and B. Hölldobler, Angew. Chem., Int. Ed. Engl., 1997, 36, 395-397.

86 J. R. Rocca, J. H. Tumlinson, B. M. Glancey and C. S. Lofgren, Tetrahedron Lett., 1983, 24, 1893-1896.

87 F. E. Ziegler, E. P. Stirchak and R. T. Wester, Tetrahedron Lett., 1986, 27, 1229-1232.

88 K. Mori and Y. Nakazono, Tetrahedron, 1986, 42, 6459-6464. 89 S. Sato, F. Iwata, S. Yamada and H. Kawahara, J. Antibiot., 2011, 64, 385-389.

90 Y.-H. Chen and F. E. McDonald, J. Am. Chem. Soc., 2006, 128, 4568-4569.

91 J. S. Yadav, K. A. Lakshmi, N. M. Reddy, A. R. Prasad and A. A. K. Al Ghamdi, Synthesis, 2012, 2595-2600.

92 Y. Zhu and K. Burgess, Adv. Synth. Catal., 2013, 355, 107115.

93 R. E. Charlton, F. X. Webster, A. Zhang, C. Schal, D. Liang, I. Sreng and W. L. Roelofs, Proc. Natl. Acad. Sci. U. S. A., 1993, 90, 10202-10205.

94 C. Gemeno, W. S. Leal, K. Mori and C. Schal, J. Chem. Ecol., 2003, 29, 1797-1811. 
95 W. S. Leal, X. Shi, D. Liang, C. Schal and J. Meinwald, Proc. Natl. Acad. Sci. U. S. A., 1995, 92, 1033-1037.

96 X. Shi, W. Soares Leal, Z. Liu, E. Schrader and J. Meinwald, Tetrahedron Lett., 1995, 36, 71-74.

97 K. Fujita and K. Mori, Eur. J. Org. Chem., 2001, 493-502.

98 L. D. Houck, Annu. Rev. Physiol., 2009, 71, 161-176.

99 S. K. Woodley, J. Comp. Physiol., A, 2010, 196, 713-727.

100 I. Starnberger, D. Poth, P. S. Peram, S. Schulz, M. Vences,

J. Knudsen, M. F. Barej, M.-O. Rödel, M. Walzl and

W. Hödl, Biol. J. Linn. Soc., 2013, 110, 828-838.

101 D. Poth, K. C. Wollenberg, M. Vences and S. Schulz, Angew. Chem., Int. Ed., 2012, 51, 2187-2190.

102 D. Poth, P. S. Peram, M. Vences and S. Schulz, J. Nat. Prod., 2013, 76, 1548-1558.

103 T. Kitahara, K. Koseki and K. Mori, Agric. Biol. Chem., 1983, 47, 389-393.

104 G. Dräger, A. Kirschning, R. Thiericke and M. Zerlin, Nat. Prod. Rep., 1996, 13, 365-375.

105 A. C. Oehlschlager, A. M. Pierce, H. D. Pierce Jr and J. H. Borden, J. Chem. Ecol., 1988, 14, 2071-2098.

106 J. W. Wong, V. Verigin, A. C. Oehlschlager, J. H. Borden, H. D. Pierce Jr, A. M. Pierce and L. Chong, J. Chem. Ecol., 1983, 9, 451-474.

107 A. C. Oehlschlager, G. G. S. King, H. D. Pierce Jr, A. M. Pierce, K. N. Slessor, J. G. Millar and J. H. Borden, J. Chem. Ecol., 1987, 13, 1543-1554.

108 D. Vanderwel, H. D. Pierce Jr, A. C. Oehlschlager, J. H. Borden and A. M. Pierce, Insect Biochem., 1990, 20, 567-572.

109 S. Hötling, B. Haberlag, M. Tamm, J. Collatz, P. Mack, J. L. M. Steidle, M. Vences and S. Schulz, Chem.-Eur. J., 2014, 20, 3183-3191.

110 C. D. J. Boden, J. Chambers and I. Stevens, Synthesis, 1993, 411-420.

111 D. Vanderwel, B. Johnston and A. Oehlschlager, Insect Biochem. Mol. Biol., 1992, 22, 875-883.

112 J. G. Millar and A. C. Oehlschlager, J. Org. Chem., 1984, 49, 2332-2338.

113 J. G. Millar, H. D. Pierce Jr, A. M. Pierce, A. C. Oehlschlager, J. H. Borden and A. V. Barak, J. Chem. Ecol., 1985, 11, 10531070.

114 K. Mori and H. Tomioka, Liebigs Ann. Chem., 1992, 10111017.

115 B. A. Cheskis, N. A. Shapiro and A. M. Moiseenkov, Russ. Chem. Bull., 1990, 38, 2389-2393.

116 S. Beer, K. Brandhorst, J. Grunenberg, C. G. Hrib, P. G. Jones and M. Tamm, Org. Lett., 2008, 10, 981-984.

117 S. Beer, K. Brandhorst, C. G. Hrib, X. Wu, B. Haberlag, J. Grunenberg, P. G. Jones and M. Tamm, Organometallics, 2009, 28, 1534-1545.

118 B. Haberlag, X. Wu, K. Brandhorst, J. Grunenberg, C. G. Daniliuc, P. G. Jones and M. Tamm, Chem.-Eur. J., 2010, 16, 8868-8877.

119 H. Takahashi, T. Kawakita, M. Ohno, M. Yoshioka and S. Kobayashi, Tetrahedron, 1992, 48, 5691-5700.

120 R. J. Bartelt, A. A. Cossé, B. W. Zilkowski and I. Fraser, J. Chem. Ecol., 2007, 33, 1299-1302.
121 P. D. Mayo, P. J. Silk, D. I. MaGee and J. McConaghy, Synth. Commun., 2014, 44, 1957-1969.

122 D. Eliyahu, S. Nojima, R. G. Santangelo, S. Carpenter, F. X. Webster, D. J. Kiemle, C. Gemeno, W. S. Leal and C. Schal, Proc. Natl. Acad. Sci. U. S. A., 2012, 109, E490-E496.

123 S. Schulz, S. Yildizhan, K. Stritzke, C. Estrada and L. E. Gilbert, Org. Biomol. Chem., 2007, 5, 3434-3441.

124 M. Miyakado, J. Meinwald and L. E. Gilbert, Experentia, 1989, 45, 1006-1008.

125 W. Leal, S. Kuwahara, X. Shi, H. Higuchi, C. B. Marino, M. Ono and J. Meinwald, J. Chem. Ecol., 1998, 24, 18171829.

126 N. Endo, R. Sasaki and S. Muto, Environ. Entomol., 2010, 39, 1973-1979.

127 S. Schulz, C. Estrada, S. Yildizhan, M. Boppré and L. E. Gilbert, J. Chem. Ecol., 2008, 34, 82-93.

128 C. Estrada, S. Schulz, S. Yildizhan and L. E. Gilbert, Evolution, 2011, 65, 2843-2854.

129 A. Hefetz, in Pheromone Communication in Social Insects, ed. R. K. Vander Meer, M. D. Breed, M. L. Winston and K. E. Espelie, Westview Press, Boulder, 1998, pp. 236-256.

130 A. Soro, M. Ayasse, M. U. Zobel and R. J. Paxton, Behav. Ecol. Sociobiol., 2011, 65, 641-653.

131 B. H. Smith, R. G. Carlson and J. Frazier, J. Chem. Ecol., 1985, 11, 1447-1456.

132 B. H. Smith and C. Weller, J. Insect Behav., 1989, 2, 397-411.

133 W. Francke, Chemoecology, 2010, 20, 163-169.

134 M. Ayasse, W. Engels, A. Hefetz, G. Luebke and W. Francke, Z. Naturforsch., C: J. Biosci., 1990, 45, 709-714.

135 R. M. Duffield, A. Fernandes, C. Lamb, J. W. Wheeler and G. C. Eickwort, J. Chem. Ecol., 1981, 7, 319-331.

136 R. M. Duffield, W. E. LaBerge, J. H. Cane and J. W. Wheeler, J. Chem. Ecol., 1982, 8, 535-543.

137 G. Bergström and J. Tengö, Acta Chem. Scand., Ser. B, 1979, 33, 390.

138 G. Bergström, Chem. Scr., 1974, 5, 39-46.

139 A. Hefetz, M. S. Blum, G. C. Eickwort and J. W. Wheeler, Comp. Biochem. Physiol., Part B: Biochem. Mol. Biol., 1978, 61, 129-132.

140 A. Hefetz, H. M. Fales and S. W. T. Batra, Science, 1979, 204, 415-417.

141 R. M. Duffield, A. Fernandes, S. McKay, J. W. Wheeler and R. R. Snelling, Comp. Biochem. Physiol., Part B: Biochem. Mol. Biol., 1980, 67, 159-162.

142 K. R. Albans, R. T. Aplin, J. Brehcist, J. F. Moore and C. O'Toole, J. Chem. Ecol., 1980, 6, 549-564.

143 J. H. Cane, J. Chem. Ecol., 1981, 7, 403-410.

144 A. Fürstner and K. Langemann, J. Org. Chem., 1996, 61, 3942-3943.

145 R. J. Bartelt, A. A. Cossé, B. W. Zilkowski, D. Weisleder, S. H. Grode, R. N. Wiedenmann and S. L. Post, J. Chem. Ecol., 2006, 32, 693-712.

146 G. Spiteller, Lipids, 2005, 40, 755-771.

147 R. J. Petroski, R. J. Bartelt and K. Vermillion, Synth. Commun., 2009, 39, 1389-1405.

148 G. Kunesch, P. Zagatti, J. Y. Lallemand, A. Debal and J. P. Vigneron, Tetrahedron Lett., 1981, 22, 5270-5274. 
149 J. P. Vigneron, R. Méric, M. Larchevêque, A. Debal, J. Y. Lallemand, G. Kunesch, P. Zagatti and M. Gallois, Tetrahedron, 1984, 40, 3521-3529.

150 H. G. Davies, S. M. Roberts, B. J. Wakefield and J. A. Winders, J. Chem. Soc., Chem. Commun., 1985, 1166.

151 T. Uematsu, T. Umemura and K. Mori, Agric. Biol. Chem., 1983, 47, 597-601.

152 T. Ehata, T. Ebata, K. Matsumoto, H. Yoshikoshi, K. Koseki, H. Kawakami and H. Matsushita, Heterocycles, 1990, 31, 1585.

153 H. Paulsen and D. Hoppe, Tetrahedron, 1992, 48, 56675670.

154 L. Kong, Z. Zhuang, Q. Chen, H. Deng, Z. Tang, X. Jia, Y. Li and H. Zhai, Tetrahedron: Asymmetry, 2007, 18, 451-454.

155 Y.-J. Li, G.-M. Ho and P.-Z. Chen, Tetrahedron: Asymmetry, 2009, 20, 1854-1863.

156 D. A. Devalankar, P. U. Karabal and A. Sudalai, Org. Biomol. Chem., 2013, 11, 1280-1285.

157 H. Tarui, N. Mori, R. Nishida, K. Okabe and Y. Kuwahara, Biosci., Biotechnol., Biochem., 2002, 66, 135-140.

158 J. Boukouvalas, J. Robichaud and F. Maltais, Synlett, 2006, 2480-2482.

159 A. Morino, Y. Kuwahara, S. Matsuyama and T. Suzuki, Biosci., Biotechnol., Biochem., 1997, 61, 1906-1908.

160 W. Francke, J. Bartels, E. Baader, S. Krohn, J. Tengo, S. Schulz and D. Schneider, Pure Appl. Chem., 1989, 61, 539-542.

161 T. Sakan, S. Isoe and S. B. Hyeon, Tetrahedron Lett., 1967, 8, 1623-1627.

162 J. A. Pickett, R. K. Allemann and M. A. Birkett, Nat. Prod. Rep., 2013, 30, 1277-1283.

163 A. J. Hick, M. C. Luszniak and J. A. Pickett, Nat. Prod. Rep., 1999, 16, 39-54.

164 K. S. Boo, M. Y. Choi, I. B. Chung, V. F. Eastop, J. A. Pickett, L. J. Wadhams and C. M. Woodcock, J. Chem. Ecol., 2000, 26, 601-609.

165 C. A. M. Campbell, F. J. Cook, J. A. Pickett, T. W. Pope, L. J. Wadhams and C. M. Woodcock, J. Chem. Ecol., 2003, 29, 2225-2234.

166 S. H. Goldansaz, S. Dewhirst, M. A. Birkett, A. M. Hooper, D. W. M. Smiley, J. A. Pickett, L. Wadhams and J. N. McNeil, J. Chem. Ecol., 2004, 30, 819-834.

167 B.-Y. Han, M.-X. Wang, Y.-C. Zheng, Y.-Q. Niu, C. Pan, L. Cui, K. R. Chauhan and Q.-H. Zhang, Chemoecology, 2014, 24, 179-187.

168 M. Pettersson, C. R. Unelius, I. Valterová and A.-K. BorgKarlson, J. Chromatogr. A, 2008, 1180, 165-170.

169 A. Stewart-Jones, S. Y. Dewhirst, L. Durrant, J. D. Fitzgerald, J. Hardie, A. M. Hooper, J. A. Pickett and G. M. Poppy, J. Exp. Biol., 2007, 210, 4335-4344.

170 E. J. Symmes, S. Y. Dewhirst, M. A. Birkett, C. A. M. Campbell, K. Chamberlain, J. A. Pickett and F. G. Zalom, J. Chem. Ecol., 2012, 38, 576-583.

171 R. W. H. M. van Tol, H. H. M. Helsen, F. C. Griepink and W. J. de Kogel, Bull. Entomol. Res., 2009, 99, 593-602.

172 R. T. Glinwood, Y. J. Du, D. W. M. Smiley and W. Powell, J. Chem. Ecol., 1999, 25, 1481-1488.
173 M. A. Birkett and J. A. Pickett, Phytochemistry, 2003, 62, 651656.

174 G. W. Dawson, D. C. Griffiths, L. A. Merritt, A. Mudd, J. A. Pickett, L. J. Wadhams and C. M. Woodwock, Entomol. Exp. Appl., 1988, 48, 91-93.

175 C. A. Campbell, G. W. Dawson, D. C. Griffiths, J. Pettersson, J. A. Pickett, L. J. Wadhams and C. M. Woodcock, J. Chem. Ecol., 1990, 16, 3455-3465.

176 K. Sakurai, K. Ikeda and K. Mori, Agric. Biol. Chem., 1988, 52, 2369-2371.

177 J. Stökl, J. Hofferberth, M. Pritschet, M. Brummer and J. Ruther, J. Chem. Ecol., 2012, 38, 331-339.

178 I. Weiss, T. Rössler, J. Hofferberth, M. Brummer, J. Ruther and J. Stökl, Nat. Commun., 2013, 4, 2767.

179 D.-H. Choe, D. B. Villafuerte and N. D. Tsutsui, PLoS One, 2012, 7, e45016.

180 R. Hilgraf, N. Zimmermann, L. Lehmann, A. Troeger and W. Francke, Beilstein J. Org. Chem., 2012, 8, 12561264.

181 N. Zimmermann, R. Hilgraf, L. Lehmann, D. Ibarra and W. Francke, Beilstein J. Org. Chem., 2012, 8, 1246-1255.

182 S. Yildizhan, J. A. van Loon, A. Sramkova, M. Ayasse, C. Arsene, C. ten Broeke and S. Schulz, ChemBioChem, 2009, 10, 1666-1677.

183 A. C. Oehlschlager, J. W. Wong, V. G. Verigin and H. D. Pierce Jr, J. Org. Chem., 1983, 48, 5009-5017.

184 M. A. Battiste, L. Strekowski, D. P. Vanderbilt, M. Visnick, R. W. King and J. L. Nation, Tetrahedron Lett., 1983, 24, 2611-2614.

185 T. Chuman, J. Sivinski, R. R. Heath, C. O. Calkins, J. H. Tumlinson, M. A. Battiste, R. L. Wydra, L. Strekowski and J. L. Nation, Tetrahedron Lett., 1988, 29, 6561-6563.

186 J. R. Rocca, J. L. Nation, L. Strekowski and M. A. Battiste, J. Chem. Ecol., 1992, 18, 223-244.

187 I. S. Lima, P. E. House and R. R. Do Nascimento, J. Braz. Chem. Soc., 2001, 12, 196-201.

188 M. A. Battiste, L. Strekowski, J. M. Coxon, R. L. Wydra and D. B. Harden, Tetrahedron Lett., 1991, 32, 5303-5304.

189 S. S. Walse, H. T. Alborn and P. E. A. Teal, Green Chem. Lett. Rev., 2008, 1, 205-217.

190 K. Mori and Y. Nakazano, Liebigs Ann. Chem., 1988, 167174.

191 L. Strekowski and M. A. Battiste, Tetrahedron Lett., 1981, 22, 279-282.

192 A. Saito, H. Matsushita and H. Kaneko, Chem. Lett., 1984, 729-730.

193 A. G. Schultz and S. J. Kirincich, J. Org. Chem., 1996, 61, 5626-5630.

194 K. Tadano, Y. Isshiki, M. Minami and S. Ogawa, Tetrahedron Lett., 1992, 33, 7899-7902.

195 K. Tadano, Y. Isshiki, M. Minami and S. Ogawa, J. Org. Chem., 1993, 58, 6266-6279.

196 M. A. Battiste, J. R. Rocca, R. L. Wydra, J. H. Tumlinson and T. Chuman, Tetrahedron Lett., 1988, 29, 6565-6567.

197 G. Hidalgo-Del Vecchio and A. C. Oehlschlager, J. Org. Chem., 1994, 59, 4853-4857. 
198 S. S. Walse, F. Lu and P. E. A. Teal, J. Nat. Prod., 2008, 71, 1726-1731.

199 K. Stritzke, S. Schulz and M. Boppré, Eur. J. Org. Chem., 2003, 1337-1342.

200 H. Yasui, T. Akino, T. Yasuda, M. Fukaya, S. Wakamura and H. Ono, Tetrahedron Lett., 2007, 48, 2395-2400.

201 H. Yasui, Appl. Entomol. Zool., 2009, 44, 183-194.

202 K. Mori, Tetrahedron Lett., 2007, 48, 5609-5611.

203 E. Übler, F. Kern and H. J. Bestmann, Naturwissenschaften, 1995, 82, 523-525.

204 E. Kohl, B. Hölldobler and H.-J. Bestmann, Chemoecology, 2003, 13, 113-122.

205 H. J. Bestmann, F. Kern, D. Schäfer and M. C. Witschel, Angew. Chem., 1992, 104, 757-758.

206 F. Kern, R. W. Klein, E. Janssen, H.-J. Bestmann, A. B. Attygalle, D. Schäfer and U. Maschwitz, J. Chem. Ecol., 1997, 23, 779-792.

207 A. B. Attygalle, B. Siegel, O. Vostrowsky, H. J. Bestmann and U. Maschwitz, J. Chem. Ecol., 1989, 15, 317-328.

208 H. L. Voegtle, T. H. Jones, D. W. Davidson and R. R. Snelling, J. Chem. Ecol., 2008, 34, 215-219.

209 G. Kunesch, P. Zagatti, A. Pouvreau and R. Cassini, Z. Naturforsch., C: J. Biosci., 1987, 42, 657-659.

210 H. Nago and M. Matsumoto, Biosci., Biotechnol., Biochem., 1994, 58, 1267-1272.

211 G. Herzner, A. Schlecht, V. Dollhofer, C. Parzefall, K. Harrar, A. Kreuzer, L. Pilsl and J. Ruther, Proc. Natl. Acad. Sci. U. S. A., 2013, 110, 1369-1374.

212 A. S. K. Hashmi, B. Bechem, A. Loos, M. Hamzic, F. Rominger and H. Rabaa, Aust. J. Chem., 2014, 67, 481499.

213 A. Eberhard, A. L. Burlingame, C. Eberhard, G. L. Kenyon, K. H. Nealson and N. J. Oppenheimer, Biochemistry, 1981, 20, 2444-2449.

214 T. R. I. Cataldi, G. Bianco, S. Abate and I. Losito, Rapid Commun. Mass Spectrom., 2011, 25, 1817-1826.

215 C. Ortori, S. Atkinson, S. Chhabra, M. Cámara, P. Williams and D. Barrett, Anal. Bioanal. Chem., 2007, 387, 497-511.

216 T. Ando, S. I. Inomata and M. Yamamoto, in The chemistry of pheromones and other semiochemicals, Vol. I, ed. S. Schulz, Springer, Berlin, 2004, vol. 239.

217 A. L. Schaefer, E. P. Greenberg, C. M. Oliver, Y. Oda, J. J. Huang, G. Bittan-Banin, C. M. Peres, S. Schmidt, K. Juhaszova, J. R. Sufrin and C. S. Harwood, Nature, 2008, 454, 595-599.

218 E. V. Stabb, A. Schaefer, J. L. Bose and E. G. Ruby, in Chemical communication among bacteria, ed. S. C. Winans and B. L. Bassler, ASM Press, Washington, DC, 2008, pp. 233-250.

219 D. M. Sitnikov, J. B. Schineller and T. O. Baldwin, Mol. Microbiol., 1995, 17, 801-812.

220 J. E. González and M. M. Marketon, Microbiol. Mol. Biol. Rev., 2003, 67, 574-592.

221 P. D. Perez, J. T. Weiss and S. J. Hagen, BMC Syst. Biol., 2011, 5, 153.

222 A. W. Decho, R. L. Frey and J. L. Ferry, Chem. Rev., 2010, 111, 86-99.
223 A. W. Decho, P. T. Visscher, J. Ferry, T. Kawaguchi, L. He, K. M. Przekop, R. S. Norman and R. P. Reid, Environ. Microbiol., 2009, 11, 409-420.

224 L. Hmelo and B. A. S. Van Mooy, Aquat. Microb. Ecol., 2009, 54, 127-133.

225 M. E. A. Churchill and J. P. Herman, in Chemical communication among bacteria, ed. S. C. Winans and B. L. Bassler, ASM Press, Washington, DC, 2008, pp. 275-289.

226 A. Lindemann, G. Pessi, A. L. Schaefer, M. E. Mattmann, Q. H. Christensen, A. Kessler, H. Hennecke, H. E. Blackwell, E. P. Greenberg and C. S. Harwood, Proc. Natl. Acad. Sci. U. S. A., 2011, 108, 16765-16770.

227 N. A. Ahlgren, C. S. Harwood, A. L. Schaefer, E. Giraud and E. P. Greenberg, Proc. Natl. Acad. Sci. U. S. A., 2011, 108, 7183-7188.

228 K. Kai, K. Kasamatsu and H. Hayashi, Tetrahedron Lett., 2012, 53, 5441-5444.

229 K. Kai, K. Furuyabu, A. Tani and H. Hayashi, ChemBioChem, 2012, 13, 1776-1784.

230 A. Neumann, D. Patzelt, I. Wagner-Döbler and S. Schulz, ChemBioChem, 2013, 14, 2355-2361.

231 I. Wagner-Döbler, V. Thiel, L. Eberl, M. Allgaier, A. Bodor, S. Meyer, S. Ebner, A. Hennig, R. Pukall and S. Schulz, ChemBioChem, 2005, 6, 2195-2206.

232 C. G. N. Penalver, D. Morin, F. Cantet, O. Saurel, A. Milon and J. A. Vorholt, FEBS Lett., 2006, 580, 561-567.

233 D. Patzelt, H. Wang, I. Buchholz, M. Rohde, L. Gröbe, S. Pradella, A. Neumann, S. Schulz, S. Heyber, K. Münch, R. Münch, D. Jahn, I. Wagner-Döbler and J. Tomasch, ISME J., 2013, 7, 2274-2286.

234 C. H. Tan, K. S. Koh, C. Xie, M. Tay, Y. Zhou, R. Williams, W. J. Ng, S. A. Rice and S. Kjelleberg, ISME J., 2014, 8, 1186-1197.

235 R. J. Case, M. Labbate and S. Kjelleberg, ISME J., 2008, 2, 345-349.

236 C.-S. Tsai and S. C. Winans, Mol. Microbiol., 2010, 77, 10721082.

237 A. O. Brachmann, S. Brameyer, D. Kresovic, I. Hitkova, Y. Kopp, C. Manske, K. Schubert, H. B. Bode and R. Heermann, Nat. Chem. Biol., 2013, 9, 573-578.

238 M. Chu, R. Mierzwa, L. Xu, L. He, J. Terracciano, M. Patel, W. Zhao, T. A. Black and T. M. Chan, J. Antibiot., 2002, 55, 215-218.

239 F. Kong, M. P. Singh and G. T. Carter, J. Nat. Prod., 2005, 68, 920-923.

240 S. Schulz, ChemBioChem, 2014, 15, 498-500.

241 S. Horinouchi, in Chemical communication among bacteria, ed. S. C. Winans and B. L. Bassler, ASM Press, Washington, DC, 2008, pp. 353-377.

242 E. Takano, Curr. Opin. Microbiol., 2006, 9, 287-294.

243 S. Horinouchi, K. Ueda, J. Nakayama and T. Ikeda, in Comprehensive Natural Products II, ed. L. N. Mander and H.-W. Liu, Elsevier, Oxford, 2010, vol. 4, pp. 283-337, ed. K. Mori.

244 K. Mori, Tetrahedron Lett., 1981, 22, 3431-3432.

245 K. Mori, Tetrahedron, 1983, 39, 3107-3109.

246 K. Mori, Bioorg. Med. Chem., 2007, 15, 7505-7523. 
247 A. S. Khokhlov, I. I. Tovarova, L. N. Borisova, S. A. Pliner, L. N. Shevchenko, E. Y. Kornitskaia, N. S. Ivkina and I. A. Rapoport, Dokl. Akad. Nauk SSSR, 1967, 177, 232-235. 248 Y. Yamada, K. Sugamura, K. Kondo, M. Yanagimoto and H. Okada, J. Antibiot., 1987, 40, 496-504.

249 K. Hashimoto, T. Nihira, S. Sakuda and Y. Yamada, J. Ferment. Bioeng., 1992, 73, 449-455.

250 E. Takano, T. Nihira, Y. Hara, J. J. Jones, C. J. L. Gershater, Y. Yamada and M. Bibb, J. Biol. Chem., 2000, 275, 1101011016.

251 G. Liu, K. F. Chater, G. Chandra, G. Niu and H. Tan, Microbiol. Mol. Biol. Rev., 2013, 77, 112-143.

252 S.-U. Choi, C.-K. Lee, Y.-I. Hwang, H. Kinoshita and T. Nihira, J. Bacteriol., 2004, 186, 3423-3430.

253 S.-U. Choi, C.-K. Lee, Y.-I. Hwang, H. Kinosita and T. Nihira, Arch. Microbiol., 2003, 180, 303-307.

254 W. Chun, J. Cui and A. Poplawsky, Physiol. Mol. Plant Pathol., 1997, 51, 1-14.

255 A. Yajima, A. A. N. van Brussel, J. Schripselrna, T. Nukada and G. Yabuta, Org. Lett., 2008, 10, 2047-2050.

256 Y.-W. He, J. Wu, L. Zhou, F. Yang, Y.-Q. He, B.-L. Jiang, L. Bai, Y. Xu, Z. Deng, J.-L. Tang and L.-H. Zhang, Mol. Plant-Microbe Interact., 2011, 24, 948-957.
257 J.-y. Kato, N. Funa, H. Watanabe, Y. Ohnishi and S. Horinouchi, Proc. Natl. Acad. Sci. U. S. A., 2007, 104, 2378-2383.

258 K. Mori and N. Chiba, Liebigs Ann. Chem., 1990, 31-37.

259 K. Takabe, M. Tanaka, M. Sugimoto, T. Yamada and H. Yoda, Tetrahedron: Asymmetry, 1992, 3, 1385-1386.

260 K. Takabe, N. Mase, H. Matsumura, T. Hasegawa, Y. Iida, H. Kuribayashi, K. Adachi, H. Yoda and M. Ao, Bioorg. Med. Chem. Lett., 2002, 12, 2295-2297.

261 K. Mizuno, S. Sakuda, T. Nihira and Y. Yamada, Tetrahedron, 1994, 50, 10849-10858.

262 P. Elsner, H. Jiang, J. B. Nielsen, F. Pasi and K. A. Jorgensen, Chem. Commun., 2008, 5827-5829.

263 M. H. J. Sturme, J. Nakayama, D. Molenaar, Y. Murakami, R. Kunugi, T. Fujii, E. E. Vaughan, M. Kleerebezem and W. M. De Vos, J. Bacteriol., 2005, 187, 5224-5235.

264 J. Nakayama, Y. Cao, T. Horii, S. Sakuda, A. D. L. Akkermans, W. M. De Vos and H. Nagasawa, Mol. Microbiol., 2001, 41, 145-154.

265 J. Nakayama, Y. Cao, T. Horii, S. Sakuda and H. Nagasawa, Biosci., Biotechnol., Biochem., 2001, 65, 2322-2325.

266 K. Nishiguchi, K. Nagata, M. Tanokura, K. Sonomoto and J. Nakayama, J. Bacteriol., 2009, 191, 641-650.

267 K. Mori, Proc. Jpn. Acad., Ser. B, 2014, 90, 373-388. 